
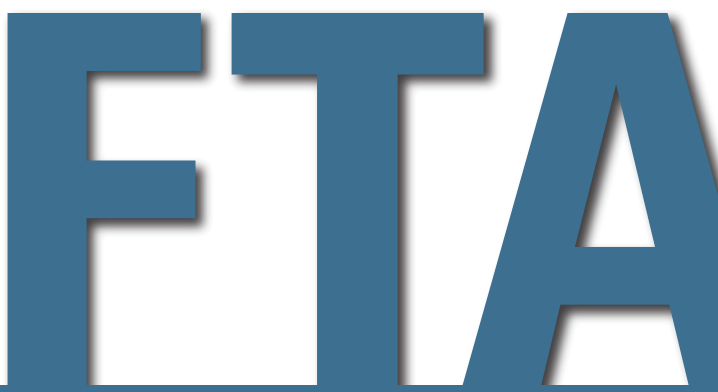

$\mathbf{R}=\mathbf{s e}$

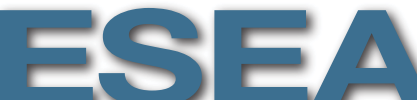

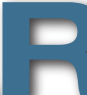

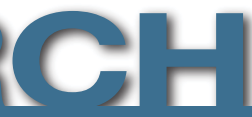

F E D E R A L

T R A N S I T

A D M I N I STRATION

\title{
WMATA Energy Storage Demonstration Project
}

Final Report

JUNE 2015

FTA Report No. 0086

Federal Transit Administration

PREPARED BY

Moustapha Ouattara

Washington Metropolitan Area Transit Authority (WMATA)

J. Gordon Yu

Gannett Fleming Transit \& Rail Systems

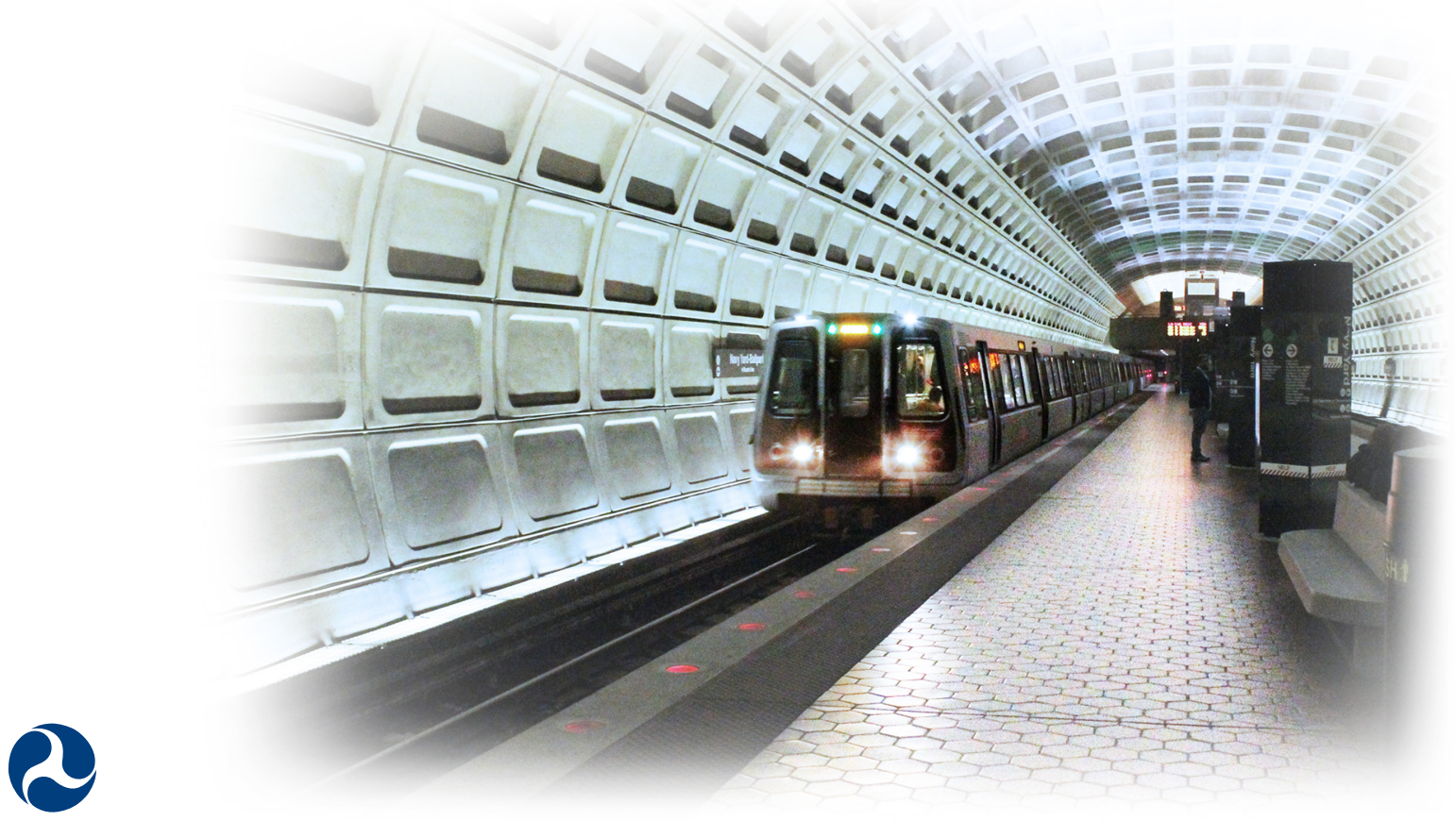

U.S. Department of Transportation

Federal Transit Administration 


\section{COVER PHOTO}

Courtesy of Edwin Adilson Rodriguez, Federal Transit Administration.

\section{DISCLAIMER}

This document is disseminated under the sponsorship of the U.S. Department of Transportation in the interest of information exchange. The United States Government assumes no liability for its contents or use thereof. The United States Government does not endorse products or manufacturers. Trade or manufacturers' names appear herein solely because they are considered essential to the objective of this report. 


\section{WMATA \\ Energy Storage \\ Demonstration \\ Project}

Final Report

JUNE 2015

FTA Report No. 0086

PREPARED BY

Moustapha Ouattara

Washington Metropolitan Area Transit Authority

(WMATA)

J. Gordon Yu

Gannett Fleming Transit \& Rail Systems

SPONSORED BY

Federal Transit Administration

Office of Research, Demonstration and Innovation U.S. Department of Transportation

1200 New Jersey Avenue, SE

Washington, DC 20590

AVAILABLE ONLINE

http://www.fta.dot.gov/research 


\section{Metric Conversion Table}

\begin{tabular}{|c|c|c|c|c|}
\hline SYMBOL & WHEN YOU KNOW & MULTIPLY BY & TO FIND & SYMBOL \\
\hline \multicolumn{5}{|c|}{ LENGTH } \\
\hline in & inches & 25.4 & millimeters & $\mathrm{mm}$ \\
\hline ft & feet & 0.305 & meters & $\mathrm{m}$ \\
\hline yd & yards & 0.914 & meters & $\mathrm{m}$ \\
\hline mi & miles & 1.61 & kilometers & $\mathrm{km}$ \\
\hline \multicolumn{5}{|c|}{ VOLUME } \\
\hline gal & gallons & 3.785 & liter & $\mathrm{L}$ \\
\hline $\mathrm{ft}^{3}$ & cubic feet & 0.028 & cubic meters & $\mathrm{m}^{3}$ \\
\hline$y d^{3}$ & cubic yards & 0.765 & cubic meters & $\mathrm{m}^{3}$ \\
\hline \multicolumn{5}{|c|}{ NOTE: volumes greater than $1000 \mathrm{~L}$ shall be shown in $\mathrm{m}^{3}$} \\
\hline \multicolumn{5}{|c|}{ MASS } \\
\hline $\mathbf{O z}$ & ounces & 28.35 & grams & $g$ \\
\hline $\mathbf{T}$ & short tons (2000 lb) & 0.907 & $\begin{array}{c}\text { megagrams } \\
\text { (or "metric ton") }\end{array}$ & Mg (or " $t$ ") \\
\hline \multicolumn{5}{|c|}{ TEMPERATURE (exact degrees) } \\
\hline${ }^{\circ} \mathbf{F}$ & Fahrenheit & $\begin{array}{c}5(F-32) / 9 \\
\text { or }(F-32) / 1.8\end{array}$ & Celsius & ${ }^{\circ} \mathrm{C}$ \\
\hline
\end{tabular}


Public reporting burden for this collection of information is estimated to average 1 hour per response, including the time for reviewing instructions, searching existing data sources, gathering and maintaining the data needed, and completing and reviewing the collection of information. Send comments regarding this burden estimate or any other aspect of this collection of information, including suggestions for reducing this burden, to Washington Headquarters Services, Directorate for Information Operations and Reports, 1215 Jefferson Davis Highway, Suite 1204, Arlington, VA 22202-4302, and to the Office of Management and Budget, Paperwork Reduction Project (0704-0188), Washington, DC 20503.

\begin{tabular}{|l|l|c|}
\hline 1. AGENCY USE ONLY & $\begin{array}{c}\text { 2. REPORT DATE } \\
\text { June } 2015\end{array}$ & $\begin{array}{c}\text { 3. REPORT TYPE AND DATES COVERED } \\
2013-2014\end{array}$ \\
\hline $\begin{array}{l}\text { 4. TITLE AND SUBTITLE } \\
\text { WMATA Wayside Energy Storage Demonstration Project }\end{array}$ & $\begin{array}{c}\text { 5. FUNDING NUMBERS } \\
\text { DC-26-7209 }\end{array}$ \\
\end{tabular}

\author{
6. AUTHOR(S) \\ Moustapha Ouattara, J. Gordon Yu
}

\begin{tabular}{|c|c|}
\hline $\begin{array}{l}\text { 7. PERFORMING ORGANIZATION NAME(S) AND ADDRESSE(ES) } \\
\text { WMATA } \\
\text { CENI-Office of Chief Engineer, Infrastructure 4C-01 } \\
600 \text { 5th St. NW } \\
\text { Washington, DC } 20001\end{array}$ & $\begin{array}{l}\text { 8. PERFORMING ORGANIZATION REPORT NUMBER } \\
\text { FTA Report No. } 0086\end{array}$ \\
\hline $\begin{array}{l}\text { 9. SPONSORING/MONITORING AGENCY NAME(S) AND ADDRESS(ES) } \\
\text { U.S. Department of Transportation } \\
\text { Federal Transit Administration } \\
\text { Office of Civil Rights } \\
\text { East Building } \\
1200 \text { New Jersey Avenue, SE } \\
\text { Washington, DC } 20590\end{array}$ & $\begin{array}{l}\text { 10. SPONSORING/MONITORING AGENCY REPORT } \\
\text { NUMBER } \\
\text { FTA Report No. } 0086\end{array}$ \\
\hline \multicolumn{2}{|l|}{ 11. SUPPLEMENTARY NOTES [http://www.fta.dot.gov/research] } \\
\hline $\begin{array}{l}\text { 12A. DISTRIBUTION/AVAILABILITY STATEMENT } \\
\text { Available from: National Technical Information Service (NTIS), Springfield, VA } 22161 . \\
\text { Phone 703.605.6000, Fax 703.605.6900, email [orders@ntis.gov] }\end{array}$ & $\begin{array}{l}\text { 12B. DISTRIBUTION CODE } \\
\text { TRI-20 }\end{array}$ \\
\hline
\end{tabular}

\title{
13. ABSTRACT
}

This report summarizes the experience and the test results from the Washington Metropolitan Area Transit Authority (WMATA) Energy Storage Demonstration Project, a project that was partially funded by the Federal Transit Administration (FTA). WMATA worked jointly with Kawasaki Rail Car, Inc., and Kawasaki Heavy Industries, Ltd., to implement the demonstration. Gannett Fleming Transit \& Rail Systems served as the technical consultant. The installation was tested under normal revenue service conditions. The test results include energy saving, peak power reduction, and train voltage support that are provided by the 2MW Battery Power System (BPS) installation. In addition, the same installation was tested as an emergency power source to move trains to desired destinations when the traction power system is under a simulated blackout situation. Based on the obtained results and the prevailing electricity cost parameters, return-on-investment calculations were performed for the installation life times of both 10 years and 20 years

\section{SUBJECT TERMS}

Regenerative braking energy recovery, energy savings for mass transit systems, emergency power for mass transit systems, energy storage applications in traction power systems
15. NUMBER OF PAGES

39

16. PRICE CODE

\begin{tabular}{|l|l|l|l|}
\hline $\begin{array}{l}\text { 17. SECURITY CLASSIFICATION } \\
\text { OF REPORT } \\
\text { Unclassified }\end{array}$ & $\begin{array}{l}\text { 18. SECURITY CLASSIFICATION } \\
\text { OF THIS PAGE } \\
\text { Unclassified }\end{array}$ & $\begin{array}{l}\text { 19. SECURITY CLASSIFICATION } \\
\text { OF ABSTRACT } \\
\text { Unclassified }\end{array}$ & 20. LIMITATION OF ABSTRACT \\
\hline
\end{tabular}


TABLE OF CONTENTS

\begin{tabular}{|c|c|}
\hline 1 & Executive Summary \\
\hline 4 & Section 1: Introduction \\
\hline 6 & $\begin{array}{l}\text { Section 2: Battery Power System (BPS) Technical Parameters } \\
\text { and Installation }\end{array}$ \\
\hline 6 & GIGACELL Battery Technology \\
\hline 8 & BPS Parameters \\
\hline 8 & BPS System Installation \\
\hline 14 & Section 3: Test Results \\
\hline 14 & BPS Test Scenarios \\
\hline 14 & Energy Savings \\
\hline 14 & Peak Power Shaving \\
\hline 15 & System Voltage Improvement \\
\hline 17 & Using BPS for Emergency Power \\
\hline 18 & Summary of Train Test Results \\
\hline 21 & Section 4: ROI Calculations \\
\hline 21 & Potential Energy Cost Savings \\
\hline 23 & Return-on-Investment \\
\hline 26 & Other Benefits \\
\hline 28 & Appendix A: Summary of Recorded Data \\
\hline 29 & Contacts \\
\hline 30 & References \\
\hline
\end{tabular}




\begin{tabular}{r|ll}
4 & Figure 1-1: & Map of Washington Metrorail Network \\
7 & Figure 2-1: & GIGACELL Specification (Type 30-K5) \\
7 & Figure 2-2: & GIGACELL Charge and Discharge Curves (Type 30-K5) \\
9 & Figure 2-3: & System Map for West End of Orange Line \\
9 & Figure 2-4: & Simplified Electrical Single Line Diagram \\
10 & Figure 2-5: & System Installation on Concrete Pad in West Falls Church \\
& & Substation \\
10 & Figure 2-6: & Two BPS Units \\
11 & Figure 2-7: & Battery Modules and Air Circulation Fixtures inside a Unit \\
12 & Figure 2-8: & Battery Monitoring Unit inside West Falls Church Substation \\
12 & Figure 2-9: & Data Acquisition and Communications Cubicle \\
15 & Figure 3-1: & Effects on Peak Power \\
15 & Figure 3-2: & Effects on Peak Power Shaving \\
16 & Figure 3-3: & Effects on Maximum Voltage Reduction at West Falls Church \\
16 & Figure 3-4: & Effects on Minimum Voltage Increase at West Falls Church \\
17 & Figure 3-5: & Effects on Voltage Stabilization at West Falls Church Substation \\
12 & Figure 4-1: & Average Prices for Electricity for Washington-Baltimore Area
\end{tabular}

\section{LIST OF TABLES}

$\begin{array}{lll}14 & \text { Table 3-1: } & \text { List of Scenarios and Test Durations } \\ 14 & \text { Table 3-2: } & \text { Summary of Annual Energy Savings by BPS } \\ 17 & \text { Table 3-3: } & \text { Summary of Test Results - BPS as an Emergency Power Source } \\ 18 & \text { Table 3-4: } & \text { Adjustment of Energy Consumption for Train Movements } \\ 19 & \text { Table 3-5: } & \text { Summary of Train Test Results - Voltage Stabilization } \\ 19 & \text { Table 3-6: } & \text { Summary of Train Test Results - Reception of Regenerated } \\ & & \text { Energy and Maximum Charging Current } \\ 21 & \text { Table 4-1: } & \text { Potential Energy Cost Savings - Scenario A } \\ 22 & \text { Table 4-2: } & \text { Potential Peak Power Cost Savings - Scenario A } \\ 23 & \text { Table 4-3: } & \text { Potential Energy Cost Savings - Scenario C } \\ 23 & \text { Table 4-4: } & \text { Potential Peak Power Cost Savings - Scenario C } \\ 24 & \text { Table 4-5: } & \text { ROI at I0 Years - Scenario A } \\ 25 & \text { Table 4-6: } & \text { ROI at I0 Years - Scenario C } \\ 25 & \text { Table 4-7: } & \text { ROI at } 20 \text { Years - Scenario A } \\ 26 & \text { Table 4-8: } & \text { ROl at } 20 \text { Years - Scenario C }\end{array}$




\title{
ACKNOWLEDGMENTS
}

This report was developed for the Federal Transit Administration's Office of Technology. Special thanks to Roy Chen, Transportation Engineer, for his guidance and support. The demonstration project at WMATA would not have been possible without the support and cooperation of many people. The authors also thank the following:

\section{WMATA}

Ashton Robinson

Oscar Ravarra

Wayne Ficklin

\author{
Kawasaki Rail Car, Inc. \\ John Calvello \\ Willard Francis \\ Maurice Andriani

\section{Kawasaki Heavy Industries, Ltd.} \\ Shoichi Morioka \\ Takahiro Matsumura \\ Koki Ogura
}

\section{ABSTRACT}

This report summarizes the experience and the test results from the Washington Metropolitan Area Transit Authority (WMATA) Energy Storage Demonstration Project, a project that was partially funded by the Federal Transit Administration (FTA). WMATA worked jointly with Kawasaki Rail Car, Inc., and Kawasaki Heavy Industries, Ltd., to implement the demonstration. Gannett Fleming Transit \& Rail Systems served as the technical consultant.

The installation was tested under normal revenue service conditions. The test results include energy saving, peak power reduction, and train voltage support that are provided by the 2MW Battery Power System (BPS) installation. In addition, the same installation was tested as an emergency power source to move trains to desired destinations when the traction power system is under a simulated blackout situation. Based on the obtained results and the prevailing electricity cost parameters, return-on-investment calculations were performed for the installation life times of both 10 years and 20 years. 


\section{EXECUTIVE SUMMARY}

This report presents the results of the WMATA Energy Storage Demonstration Project.

The rail cars in the WMATA Metrorail system use regenerative braking to recover a substantial amount of energy that otherwise would have been wasted. The ratio of the recovered energy over the available energy (defined as the receptivity of the system) depends primarily on the service frequency, among other factors. An energy storage system helps with the additional recovery of the braking energy. It also helps reduce peak power demands from substations and reduce the voltage drops to motoring trains. WMATA decided to install a demonstration unit and collect in-service data to quantify the benefits of such a system and determine the return on investment. Such data are not only useful to WMATA, but also to other rail agencies. FTA partially sponsored this demonstration project so that the experience gained from this demonstration can be shared in the wider industry.

A 2MW Battery Power System (BPS) was installed in West Falls Church Yard on the Orange Line of the WMATA metro network. The system uses the highcapacity Nickel-metal Hydride GIGACELL technology by Kawasaki Heavy Industries, Ltd. The objective of the demonstration was to assess the suitability and effectiveness of the system in a mass rapid transit rail environment.

Electronic data recorders have been used to collect the real-time performance data. This report contains the analysis of the test results.

Three scenarios were tested:

- Scenario A - West Falls Church substation with 6MW rectifiers

- Scenario B - West Falls Church substation with 3MW rectifiers

- Scenario C - West Falls Church substation without any rectifier, acting as a tie-breaker station

In each scenario, the BPS was turned off for one week and then turned on for the next week to assess its effects. The results from the available test data are summarized as follows:

- Energy saving - Equivalent annual energy saving between 7.2\% (Scenario A) and $15.4 \%$ (Scenario C) was achieved. (Energy saving for Scenario B was not calculated because the data were incomplete due to train operational anomalies during the test.)

- Peak power shaving - Peak power shaving between I2I kW (Scenario A) and 436 kW (Scenario C) was achieved.

- System voltage improvement - Voltage stabilization effect between $42 \mathrm{~V}$ (Scenario A) and I39 V (Scenario C) was achieved. 
- Emergency power - Powered by the BPS alone, a 6-car train without passengers (AWO load) started from standstill and moved 2,800 feet at a speed limit of $10 \mathrm{mph}$. This train movement consumed $4 \%$ of the BPS energy capacity. If the train had been loaded at crush load (AW2 load at 175 passengers per car), the same train movement would have consumed $5.24 \%$ of the BPS energy capacity. From this test, it was calculated that the fullycharged BPS can support 19 such train movements at AW2 load in succession if the BPS is not used to supply any other load.

The test results demonstrate that the when the BPS is installed at a tie-breaker station, it yields better results than an equivalent installation in a traction power substation for the same battery system configuration.

Return-on-investment (ROI) calculations were performed based on the following parameters:

- Average electricity price of $\$ 0.124 / \mathrm{kWh}$ for the Washington-Baltimore area [4]

- National average electric energy price increase from 2013 to 2040 of $2.4 \%$ per year [3].

- Maintenance cost of BPS assumed to increase by $2 \%$ per year.

For a 10 -year installation, the following results were obtained:

- For Scenario A, equipment cost (offset by additional benefits and cost for displaced investment) needs to be at or less than $\$ 730,000$ for the system to achieve a positive financial return.

- For Scenario C, equipment cost (offset by additional benefits and cost for displaced investment) needs to be at or less than $\$ 1,870,000$ for the system to achieve a positive financial return.

For a 20-year installation, the following results were obtained:

- For Scenario A, equipment cost (offset by additional benefits and cost for displaced investment) needs to be at or less than $\$ 410,000$ for the system to achieve a positive financial return.

- For Scenario C, equipment cost (offset by additional benefits and cost for displaced investment) needs to be at or less than $\$ 2,650,000$ for the system to achieve a positive financial return.

Additional benefits that may be realized from a BPS include the following:

- Voltage support for trains so that the traction power system can support the desired train service levels more effectively. 
- Emergency power to trains in traction power blackout situations-this is particularly valuable in tunnel environments where the requirements for safety evacuation of passengers are more demanding than in an open-track environment.

- Significant capital cost savings if a BPS can be installed in place of one or more traditional rectifier units.

- Where the site conditions do not permit installations of traditional rectifier units, a BPS may be a viable option.

Quantification of these additional benefits is dependent on the actual situation, and the realization of these benefits may significantly improve the ROI calculation results. This is consistent with the findings from a previously-published study by the Transit Cooperative Research Program [5]: an energy storage installation in a rail transit environment is most practical when it realizes more than one benefit simultaneously rather than focusing the application primarily on solving any one problem alone. 


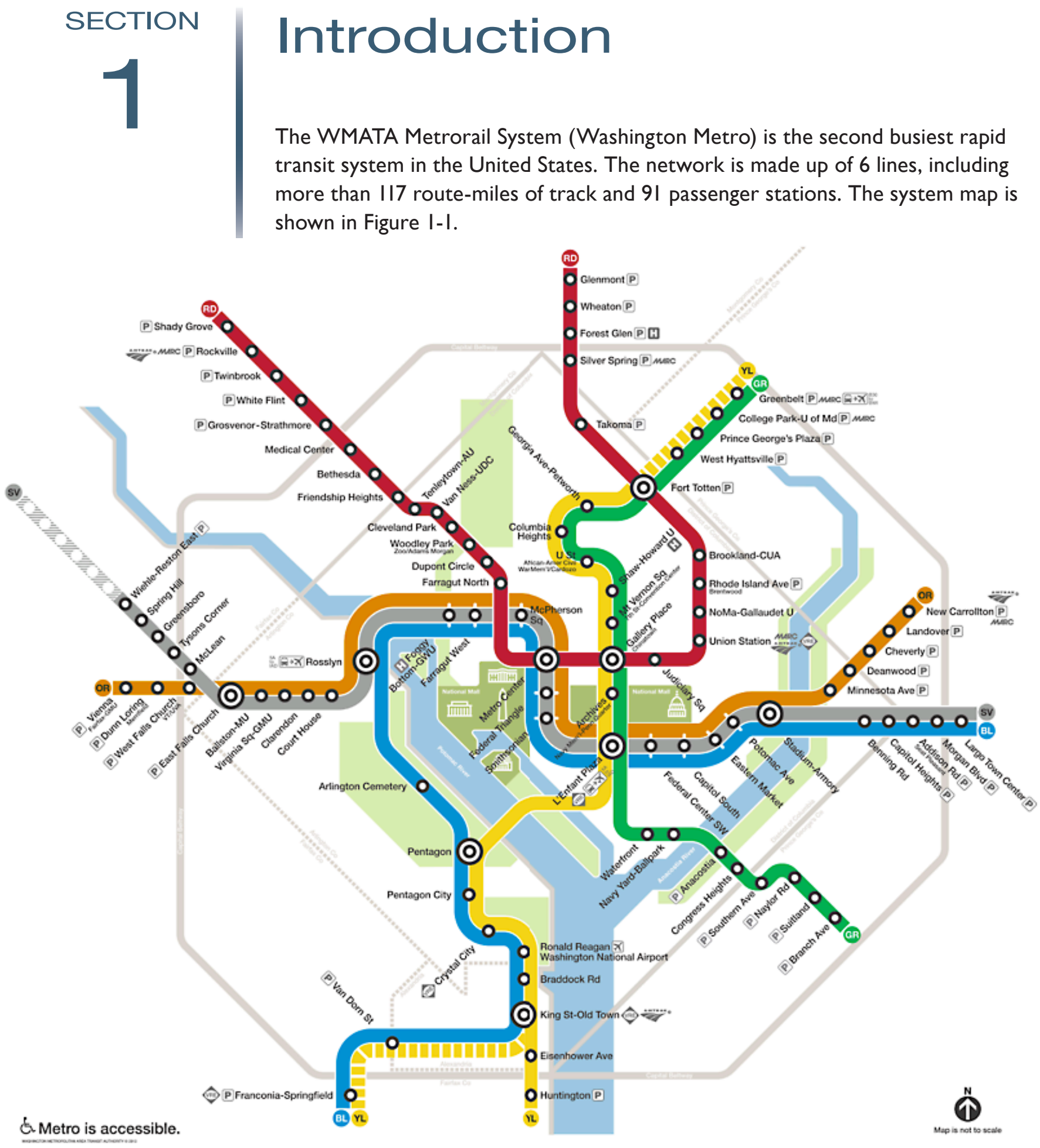

Figure 1-1

Map of Washington Metrorail Network 
At present, WMATA operates a mixture of 6-car and 8-car trains on its 6 lines. The Metro's train fleet consists of 6 types of rail cars, numbered as 1000 -series to- 6000 series. New 7000 -series cars are being tested and will be introduced into service in 2015 .

The trains are powered by more than 100 traction-power substations across the network through a $3 \mathrm{rd}$ rail $700 \mathrm{~V}$ dc distribution system. There are also more than 100 tie-breaker stations. A tie-breaker station normally is located between two adjacent substations and provides an electrical connection of the two parallel third rails associated with the power supply to the inbound and outbound tracks, so that the two tracks can share the loads and thus minimize the voltage drops to the trains.

The traction power system consumes about 500,000 MWh (MegaWatthours) per year, at a cost of approximately $\$ 48$ million. (As a comparison, the average annual electricity consumption for a U.S. residential utility customer is approximately II MWh in 2013, according to the U.S. Energy Information Administration [2]. The traction power system energy consumption is equivalent to 45,450 U.S. homes.)

All cars in operation are capable of regenerative braking, which has benefitted WMATA in energy saving and reduction in energy cost. As the amount of energy saving is dependent on the chances that trains demanding power are near trains that are generating power, a significant amount of energy is lost as heat dissipates to the surrounding environment by braking resistors. Therefore, there is a lot of potential to achieve more energy savings through the adoption of new technologies and innovations.

Furthermore, as the volume of passengers has steadily increased on the system over the years, WMATA has formulated strategic plans to meet the rising service demands by migrating to 8-car trains as a uniform standard and operating more frequent services in the future. Consequently, the traction power system needs to be upgraded to support the increased power demands.

Research has shown that wayside energy storage substations can help capture more regenerative braking energy and increase the amount of energy saving. They also can help reduce peak power demands and provide voltage support to trains. Installation of wayside storage substations also may help delay or defer some of the need for capital investment in the upgrade of the traction power system. However, since this technology is relatively new with limited operational history, WMATA decided to evaluate its effectiveness through a demonstration project.

WMATA conducted an extensive initial assessment of different wayside energy storage technologies, including flywheels, electrochemical capacitors, and batteries. Subsequently, WMATA focused on the battery technology. After discussions with several battery vendors, WMATA selected GIGACELL battery for this demonstration project. 


\section{SECTION 2 \\ Battery Power System (BPS) Technical Parameters and Installation}

\section{GIGACELL Battery Technology}

GIGACELL is a state-of-art high capacity Nickel-metal Hydride (Ni-MH) battery developed by Kawasaki Heavy Industries, Ltd [I]. It has the following features:

- High scalability - Bipolar 3D design increases both the number and capacity of cells

- Rapid charge and discharge - Low internal resistance enables fast charging and discharging capability

- Excellent cycle durability - Designed to withstand frequent cycles of short, rapid charging and discharging requirements

- Simplicity and safety - Low operating temperature, water-based electrolyte eliminates risk of fire

- Environment-friendly - No use of lead, mercury, cadmium, or other toxic materials

- Ease of recycling - Easy to disassemble for recycling since no welding is used

Based on the GIGACELL battery, Kawasaki has developed the BPS technology specifically for rail and transit applications. A number of demonstration and commercial installations have been in operation in the rail and transit environment, including Osaka Municipal Transportation Bureau, Tokyo Monorail, East Japan Railway, and New York City Subway.

The fundamental element of the battery is a cell. Each individual cell has a nominal voltage of I.2V. The cells are arranged in series to form a module. For the WMATA BPS installation, the Type $30-\mathrm{K} 5$ module is used. This module has 30 cells connected in series, with a nominal voltage of $36 \mathrm{~V}$.

Specifications for the Type 30-K5 module are shown in Figure 2-I. 
Figure 2-1

GIGACELL

Specifications

(Type 30-K5)

\begin{tabular}{|c|c|}
\hline Battery Type & $30-\mathrm{K} 5$ \\
\hline Nominal voltage & $36 \mathrm{~V}$ \\
\hline Rated capacity (I) & I4IAh \\
\hline Energy capacity & $5.1 \mathrm{kWh}$ \\
\hline Maximum output (2) & $126 \mathrm{~kW}$ \\
\hline Outline dimensions $L \times W \times H$ (3) & $1287 \times 218 \times 350 \mathrm{~mm}$ \\
\hline Volume & 98L \\
\hline Weight & $248 \mathrm{~kg}$ \\
\hline Energy density per unit volume & $52 \mathrm{Wh} / \mathrm{L}$ \\
\hline Energy density per unit weight & $21 \mathrm{Wh} / \mathrm{kg}$ \\
\hline \multicolumn{2}{|c|}{$\begin{array}{l}\text { (1) Discharge capacity when charged to I } 20 \% \text { of rated capacity. As } \\
\text { recommended capacity will depend on the operating conditions, please } \\
\text { discuss your exact application need with our representative. } \\
\text { (2) Extrapolated from results of an I-V test (0.I second discharge) } \\
\text { (3) Mounting hardware not included. } \\
\text { Specifications may change without notice. }\end{array}$} \\
\hline
\end{tabular}

Source: Kawasaki

Charging and discharging curves for type 30-K5 module are shown in Figure 2-2.

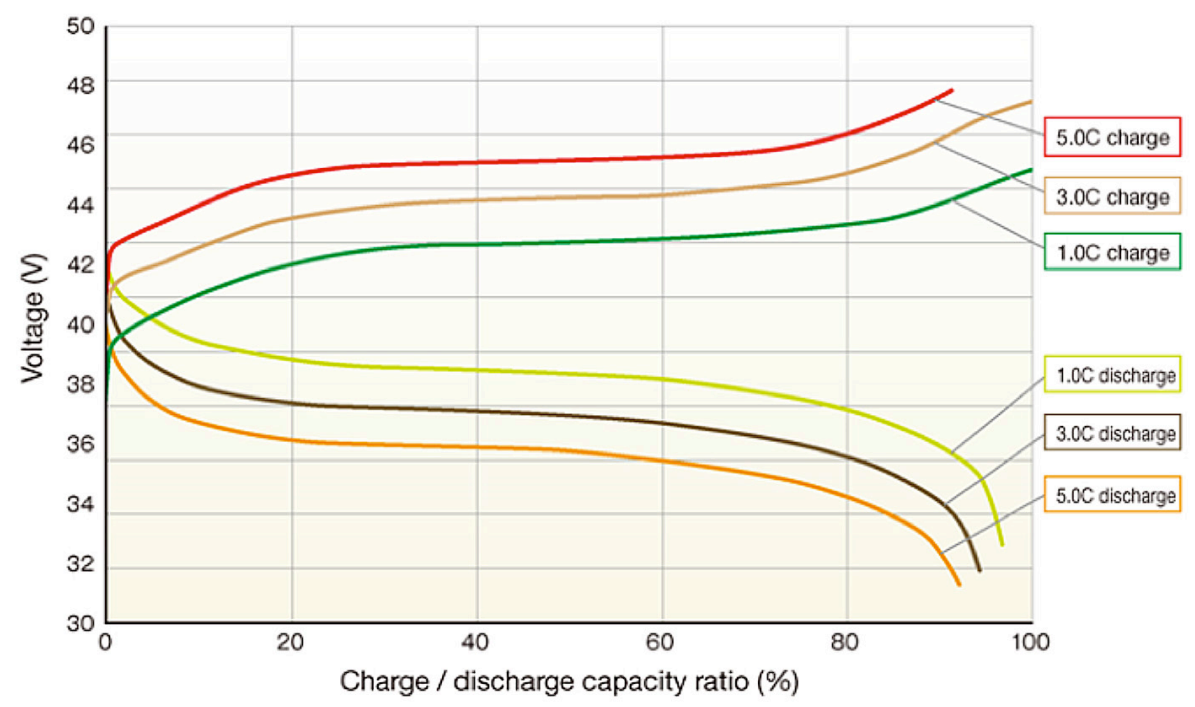

$$
\begin{array}{|l|l}
\hline \text { Test conditions } \\
\begin{array}{|l|l}
\text { Battery type } & \\
\hline \begin{array}{l}
\text { Environmental } \\
\text { temperature }
\end{array} & 20{ }^{\circ} \mathrm{C} \\
\hline
\end{array} \\
\hline
\end{array}
$$

Source: Kawasaki 
The modules can be arranged in series to form a unit to provide higher voltage levels. The units can be arranged in parallel to provide desired current rating and energy capacity.

\section{BPS Parameters}

For each module:

- Number of cells in series:

30

- Nominal voltage:

$36 \mathrm{~V}$

- Ampere-hour capacity:

I4I Ah

- Battery current at IC charge/discharge rate:

$|42 *|=|4| A$

- Battery current at 5C charge/discharge rate:

$|4| * 5=705 \mathrm{~A}$

- Energy capacity:

$14 \mid * 36 / 1000=5.076 \mathrm{kWh}$

For each unit:

- Number of full modules in series:

I8 (30 cells in series for each module)

- Number of partial module in series:

I (19 cells in series for this module)

- Total number of cells in series per unit:

$18 * 30+\mid * 19=559$ cells

- Nominal voltage per unit:

$559 * 1.2 \mathrm{~V}=670.8 \mathrm{~V}$

- Energy capacity per unit:

$5.076 \mathrm{kWh} *(18+19 / 30)=$ $94.58 \mathrm{kWh}$

For the full BPS:

- Number of units in parallel:

4

- Power rating for full system (at 5C charge/discharge rate):

$670.8 * 705 * 4 / 1000=$ I,892 kW or $2 \mathrm{MW}$

- Energy capacity of the full system:

$94.58 * 4=378.33 \mathrm{kWh}$

\section{BPS System Installation}

The BPS was installed in the West Falls Church substation located towards the west end of the Orange Line, as shown in Figure 2-3. 
Figure 2-3

System Map for West End of Orange Line

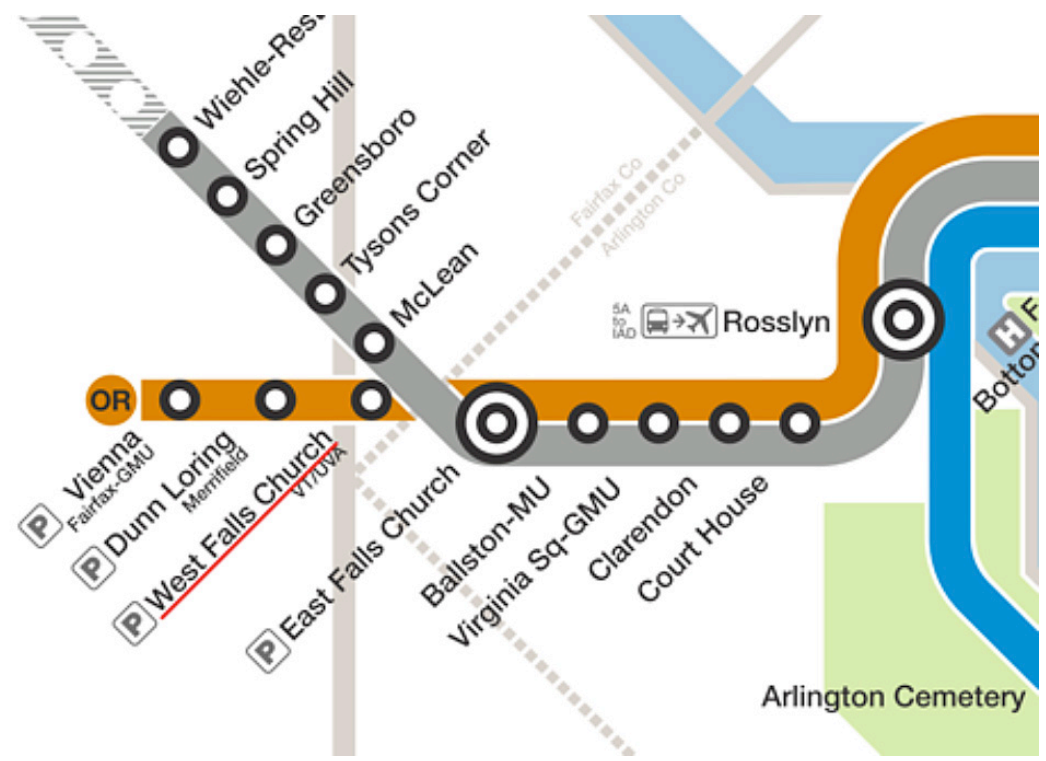

The West Falls Church substation is near the West Falls Church station. It has four rectifier units; two feed the mainline tracks and two feed the yard tracks. The dc bus for the yard tracks is normally isolated from the dc bus for the mainline tracks. The BPS is connected to the dc bus for mainline tracks.

The two substations immediately adjacent to West Falls Church substation are Barbour Road substation (west of West Falls Church substation) and Fisher Street substation (east of West Falls Church substation), as shown in Figure 2-4.

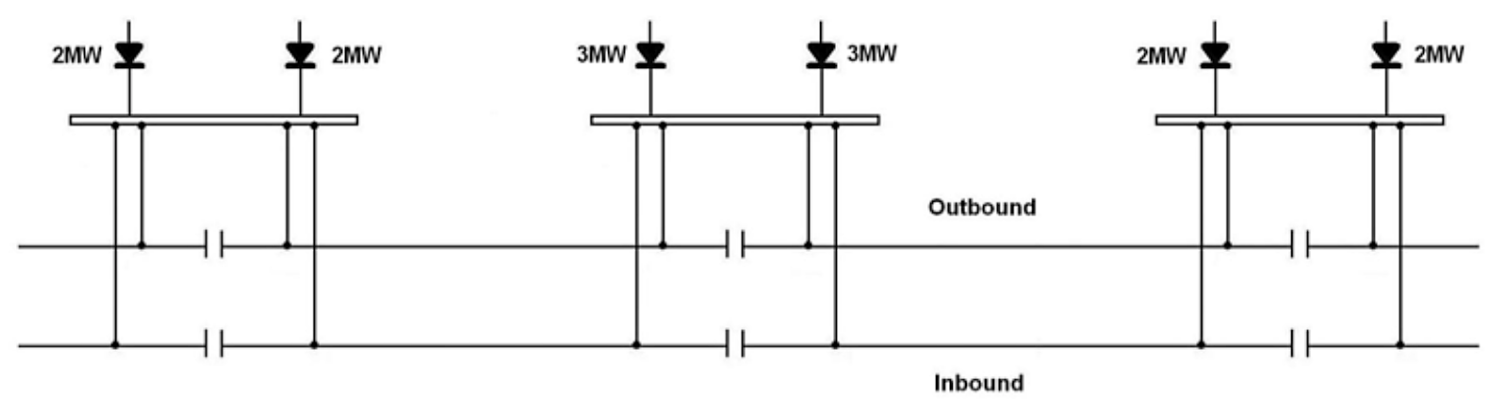

Simplified Electrical Single Line Diagram

The BPS was installed and put into service in June 2013. A photograph of the BPS installation is shown in Figure 2-5. 
Figure 2-5

System Installation on Concrete Pad in West Falls Church Substation

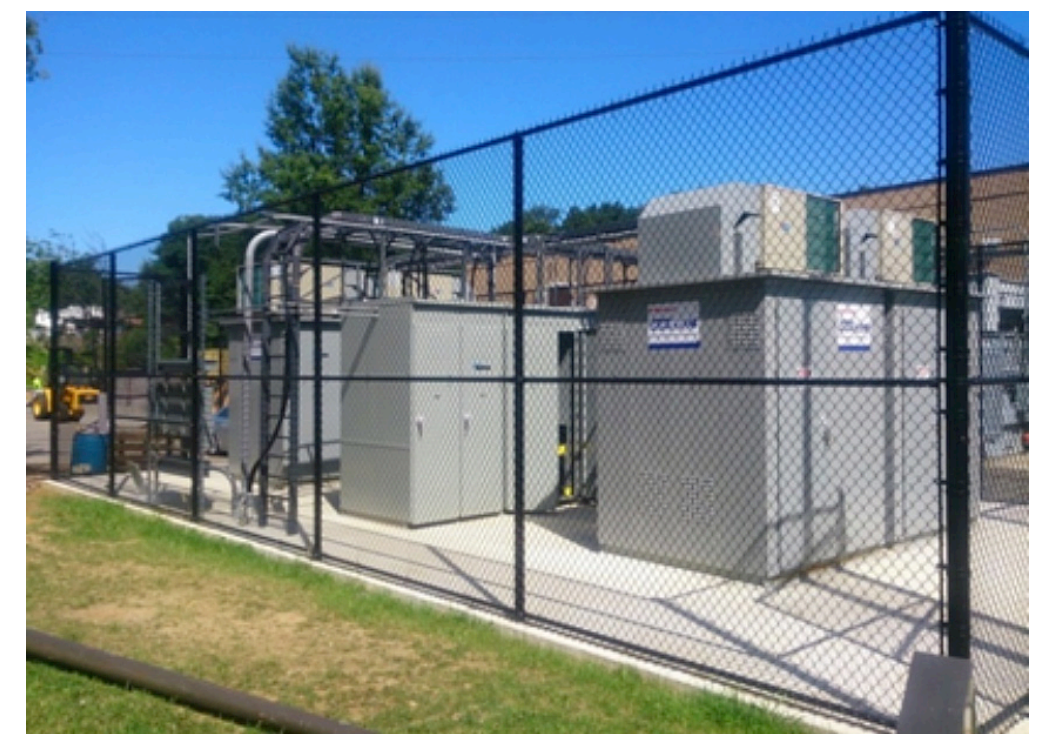

Photo courtesy of Kawasaki

As shown in Figure 2-5, the BPS units are installed on a concrete pad outside of West Falls Church substation building. The concrete pad has an overall dimension of $24^{\prime} \times 50$ '. Of the three rows of cubicles shown in the photograph, the two outside rows have four BPS units and the center row has ancillary equipment, including high speed circuit breaker, cable terminations, etc.

A closer view of the two BPS units in the front row is shown in Figure 2-6.

Figure 2-6

Two BPS Units

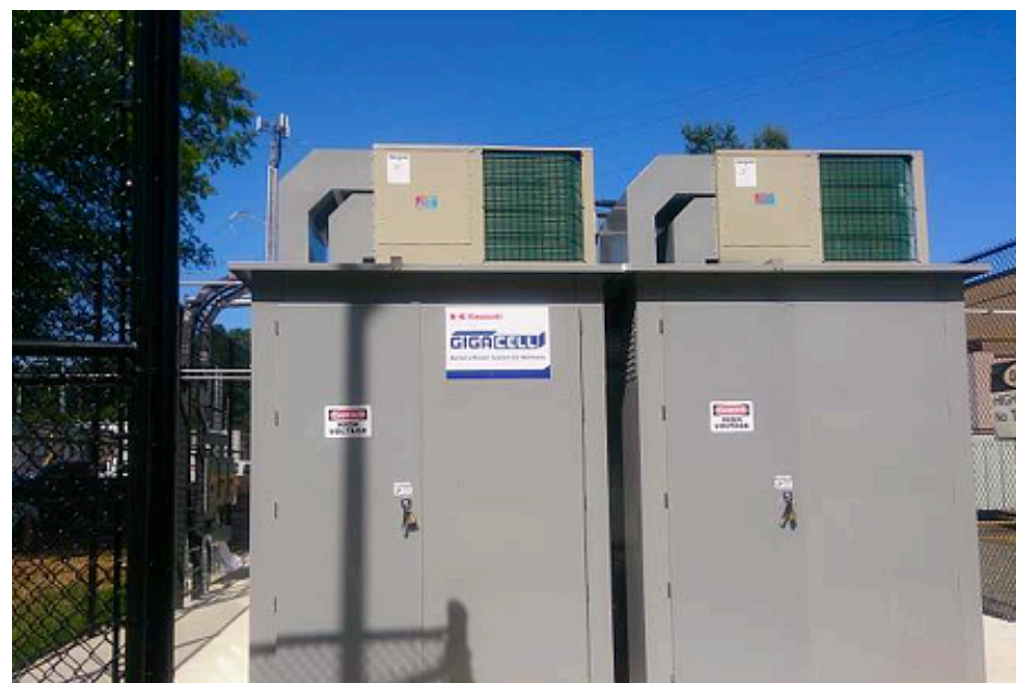

Photo courtesy of Kawasaki 
Figure 2-7

Battery Modules and Air Circulation Fixtures inside a Unit
An air-conditioning unit is installed on top of the cubicle for each BPS unit. Each air-conditioning unit has a thermal capacity of 56,000 BTU (I6.4 kWh).

Inside each BPS unit cubicle, four stacks of battery modules are housed together with air circulation fixtures for temperature control. The cubicle panels are insulated. A partial view of the internal arrangement is shown in Figure 2-7.

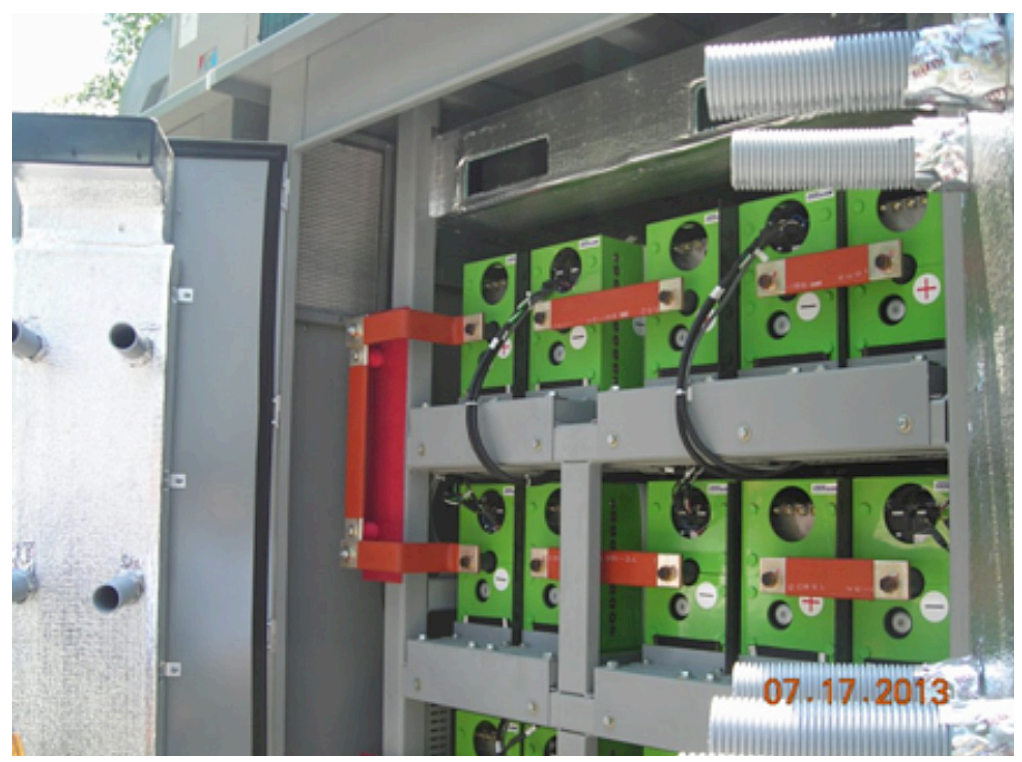

As shown in Figure 2-7, each of the four stacks can house up to five battery modules. In this particular installation, a total of 19 modules was installed, 18 of which have 30 cells each. The 19th module has 19 cells, making it a partial module $(19 / 30$, or $2 / 3)$. All battery modules within one unit are connected in series to yield the desired nominal voltage.

As part of the BPS installation, a battery monitoring system (BMS) also was installed inside the West Falls Church substation and is shown in Figure 2-8. A range of BPS parameters is monitored so that the BPS can be protected against fault conditions. These include battery temperature, pressure, cell voltage, etc. 
Figure 2-8

BMU inside West Falls

Church Substation

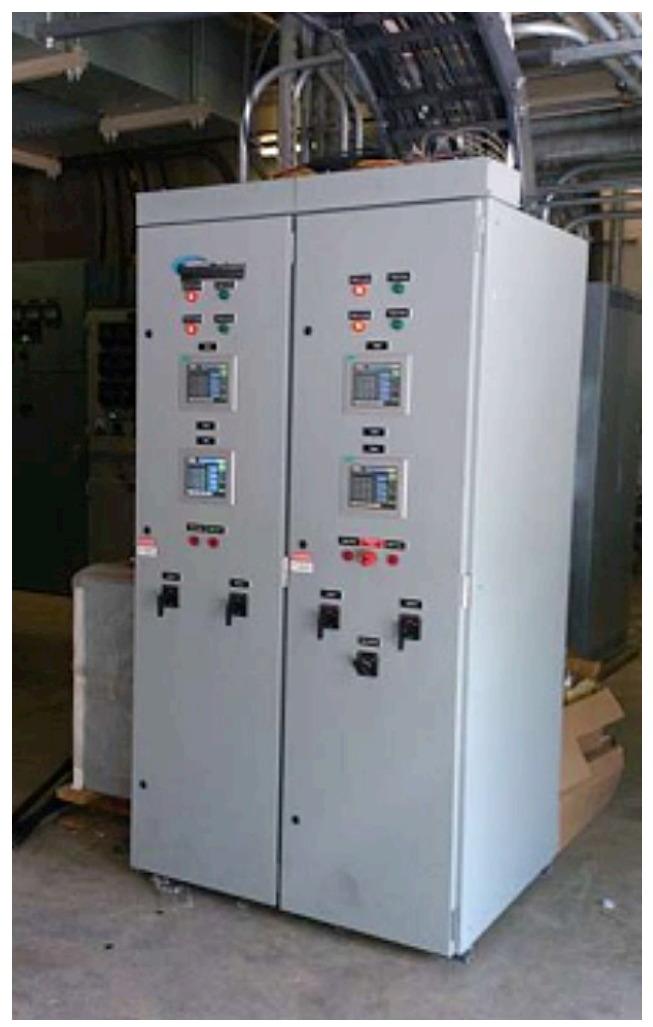

Photo courtesy of Kawasaki

A data acquisition and communications unit was installed inside the West Falls Church substation. This was mounted on the wall of the building, as shown in Figure 2-9.

Figure 2-9

Data Acquisition and

Communications

Cubicle

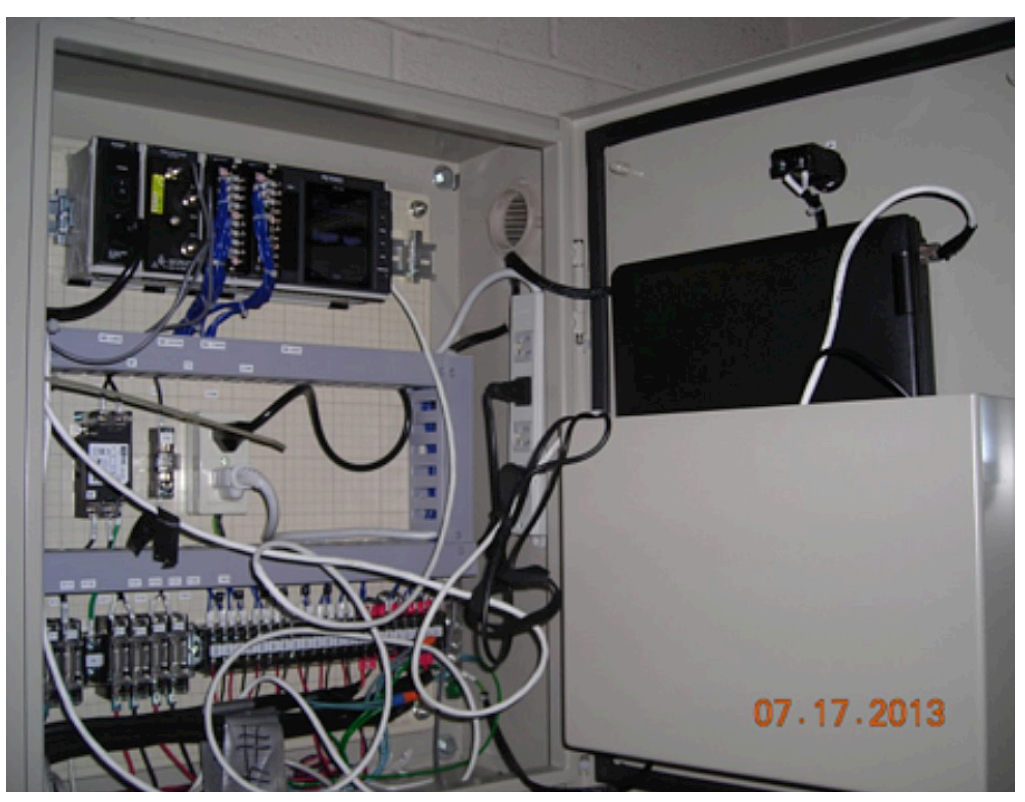


A range of data was recorded, including rectifier currents, dc bus voltage, BPS charge and discharge currents, etc. The recorded data can be accessed remotely and was downloaded regularly for analysis.

Similar data acquisition units were installed in the Barbour Road substation and the Fisher Street substation to record the substation data at those sites. 


\section{SECTION} 3

Table 3-1

List of Scenarios and Test Durations

Table 3-2

List of Scenarios and Test Durations

\section{Test Results}

\section{BPS Test Scenarios}

A number of tests were conducted to evaluate the performance of the BPS. The test scenarios are shown in Table 3-I.

\begin{tabular}{|c|c|c|c|c|c|c|}
\hline Scenarios & Tests & $\begin{array}{c}\text { Rectifier } \\
\text { Capacity } \\
\text { kW }\end{array}$ & $\begin{array}{c}\text { BPS } \\
\text { Capacity } \\
\text { kW }\end{array}$ & Start Date & End Date & $\begin{array}{c}\text { No. of } \\
\text { Days }\end{array}$ \\
\hline A & A-I & 6,000 & 0 & Monday, I0/2I/I3 & Sunday, 10/27/I3 & 7 \\
\hline B & A-2 & 6,000 & 2,000 & Monday, I0/28/13 & Sunday, II/3/13 & 7 \\
\hline C & B-I & 3,000 & 0 & Monday, 8/9/13 & Sunday, 8/25/13 & 7 \\
\hline & B-2 & 3,000 & 2,000 & Monday, 8/26/13 & Sunday, 9/1/13 & 7 \\
\hline & C-I & 0 & 0 & Monday, 9/9/13 & Sunday, 9/15/13 & 7 \\
\hline
\end{tabular}

Note: For Scenario B, weekend data were not useable for energy saving calculation due to special single-track operation for engineering work unrelated to the BPS tests.

- Scenario A - West Falls Church substation with 6MW rectifiers

- Scenario B - West Falls Church substation with 3MW rectifiers

- Scenario C - West Falls Church substation without any rectifier, acting as a tie-breaker station

A summary of the collected data is listed in Table A-I in Appendix A. This section summarizes the analysis results.

\section{Energy Savings}

For the three test scenarios, the effects of the BPS on energy saving are shown in Table 3-2.

\begin{tabular}{|l|c|c|c|}
\hline \multicolumn{1}{|c|}{ Test Designation } & Scenario A & Scenario B & Scenario C \\
\hline West Falls Church substation Rectifier Capacity (MW) & 6 & 3 & 0 \\
\hline Energy Consumption -BPS Off (MWh) & 8,897 & N/A & 8,73 I \\
\hline Energy Consumption - BPS On (MWh) & 8,255 & N/A & 7,383 \\
\hline Energy Saving (MWh) & 642 & N/A & I,347 \\
\hline Energy Saving (\%) & $7.2 \%$ & N/A & $15.4 \%$ \\
\hline
\end{tabular}

Note I: Energy consumption figures are after corrections based on daily car counts.

Note 2: Scenario B does not have complete data for annual energy consumption and energy saving calculations.

\section{Peak Power Shaving}

For the three test scenarios, the aggregated power from the three substations was calculated, and the peak power was derived. Peak power is defined as the maximum of 30-minute averages of power. (Each hour has 2 averages, making 
Figure 3-1

Effects on Peak Power

Figure 3-2

Effects on Peak Power Shaving
48 averages in one day). The effects on peak power shaving are shown in Figures 3-I and 3-2.
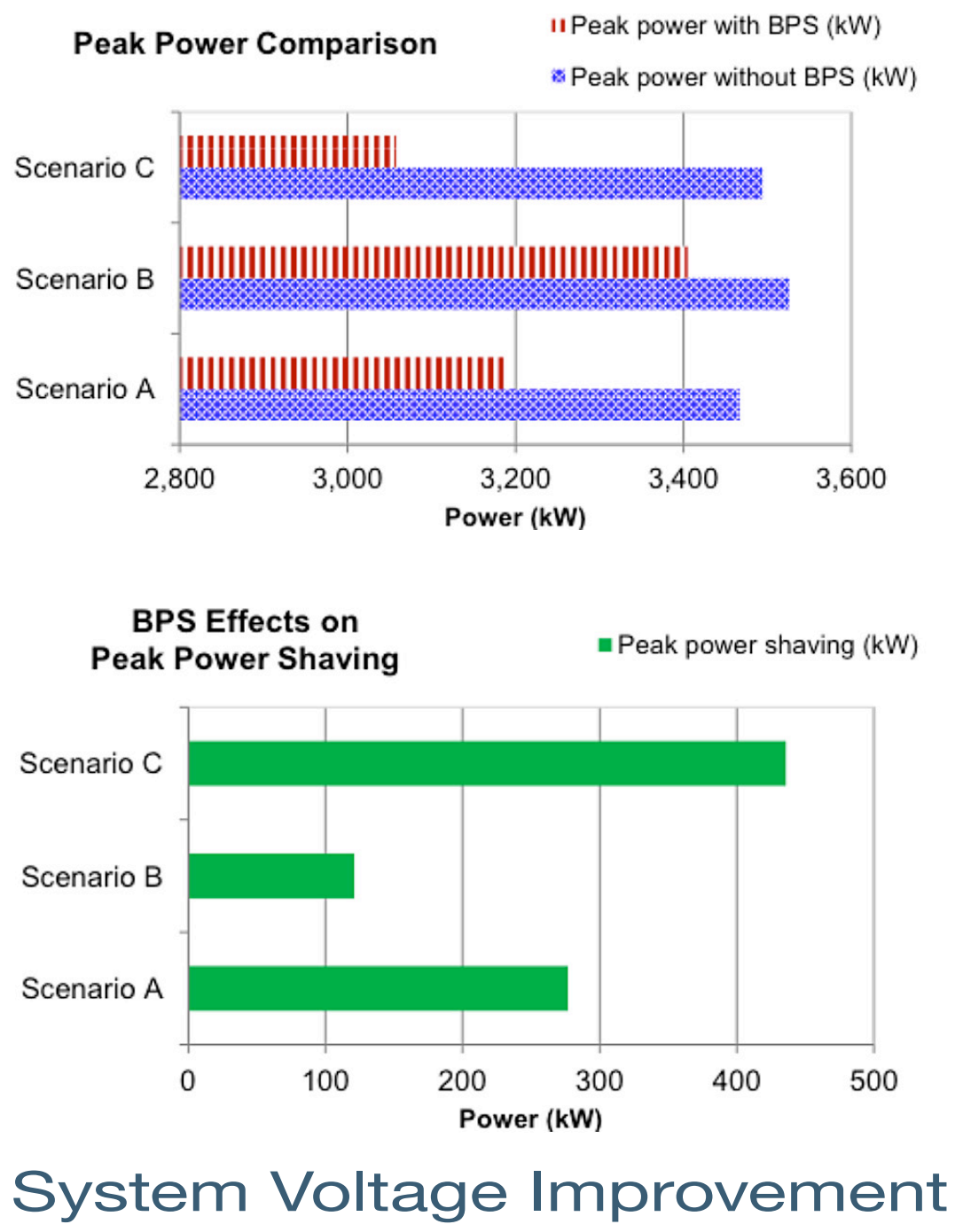

When there are one or more trains in regenerative braking mode, they feed power towards the traction power system when there are one or more trains nearby that demand power. The voltages at the regenerative trains are pushed higher as a result of the reverse power flow. If the voltage is too high, the regenerated power cannot be absorbed completely by other trains. The regenerative train will detect this excessive level of voltage and divert its excess power output to its onboard resistors. Therefore, the maximum voltage level is an indicator of how receptive the system is to absorbing the regenerated power. The higher the voltage above a certain threshold, the less receptive is the system. 
Figure 3-3

Effects on Maximum Voltage Reduction at West Falls Church Substation

Figure 3-4

Effects on Minimum Voltage Increase at West Falls Church Substation

When the BPS is in operation, it helps absorb the excessive power by charging the batteries, thus helping the system receptivity and reducing the maximum voltage. The voltages at West Falls Church substation were recorded and compared, and the effects are shown in Figure 3-3 for the three test scenarios.

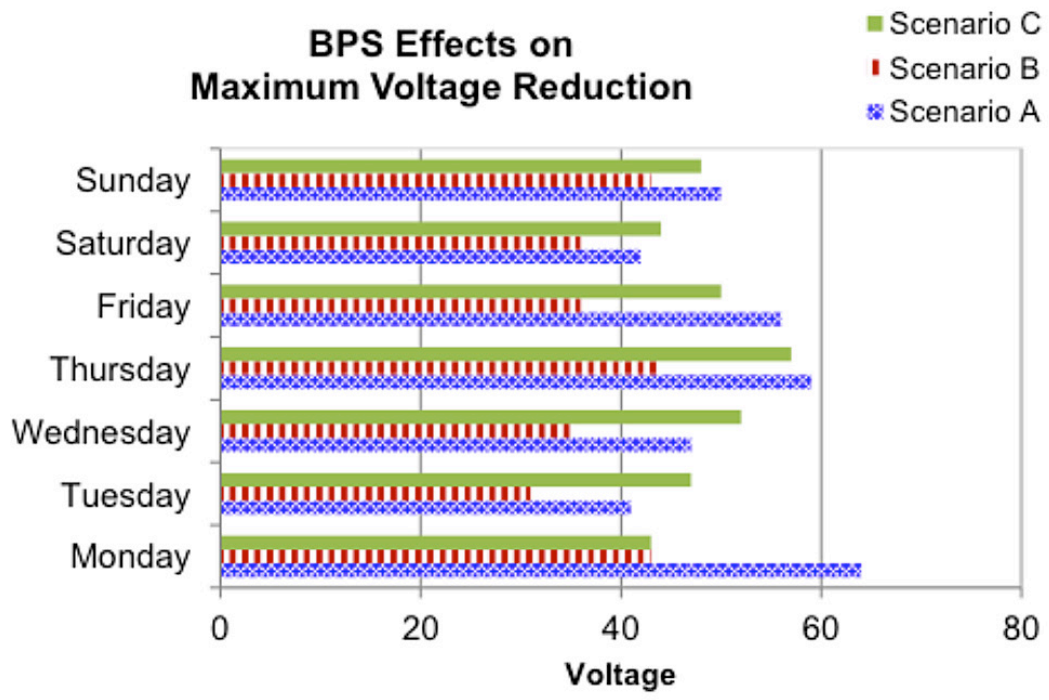

When there are one or more trains that demand power, the voltages at these trains are pushed lower. If the voltage is too low, the power demands cannot be fully met by the traction power system. As a result, some loads need to be shed. Therefore, the minimum voltage level is an indicator of how robust the system is in delivering power to meet demands. The lower the voltage, the weaker is the system.

When the BPS is in operation, it helps meeting the power demands by discharging the batteries, thus increasing the minimum voltage and improving the system robustness. The effects are shown in Figure 34 for the three test scenarios.

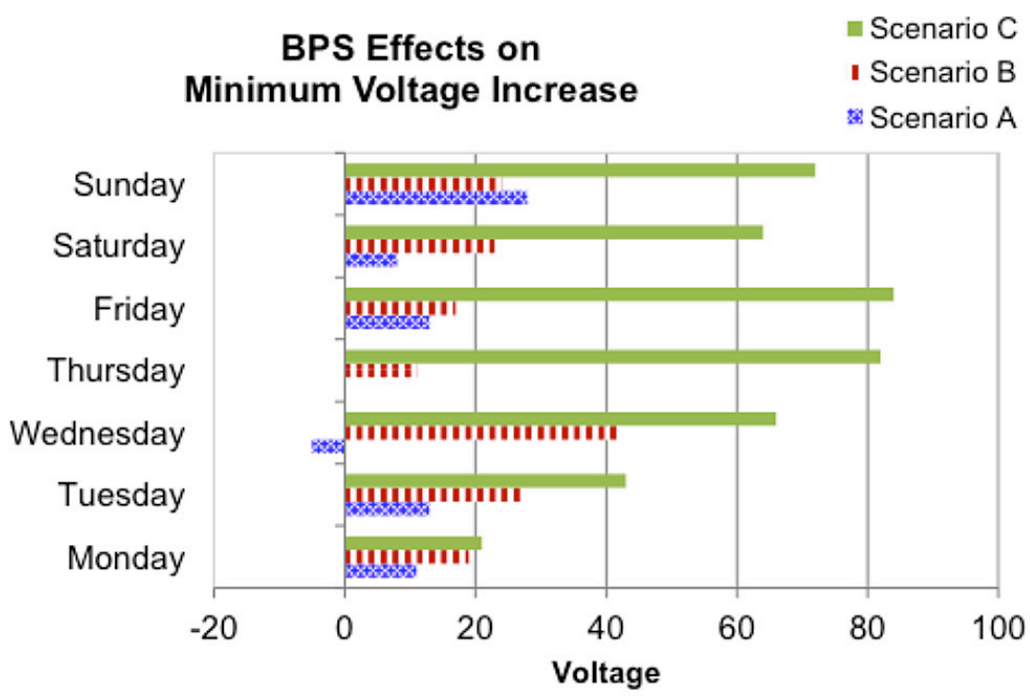


Figure 3-5

Effects on Voltage

Stabilization at

West Falls Church

Substation

\section{Table 3-3}

Summary of Test

Results - BPS as an

Emergency Power

Source
The above figures illustrate that the BPS has the effects of both maximumvoltage reduction and minimum-voltage increase. Combining these two, the overall effect is to stabilize the voltage levels more within a desired range. This overall effect is termed "voltage stabilization effect" in this report. For the three test scenarios, voltage stabilization is shown in Figure 3-5.

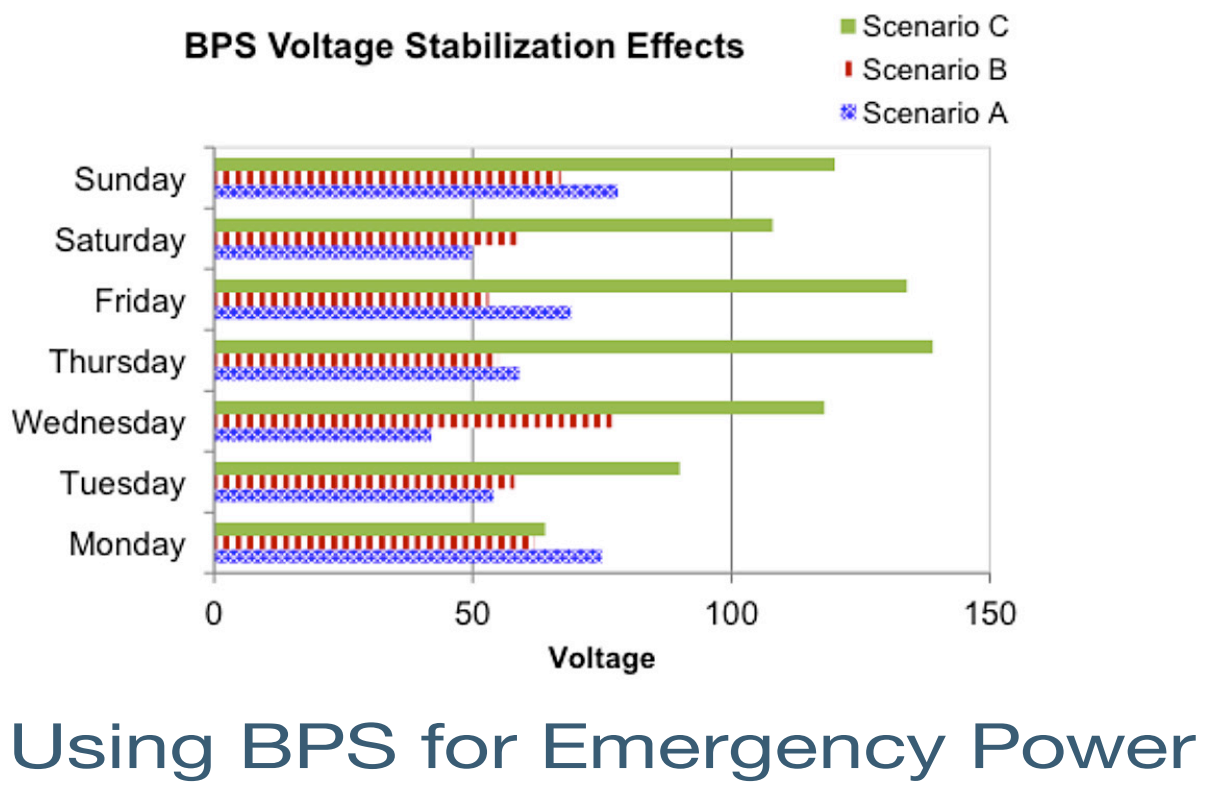

To demonstrate the interaction between the BPS and trains under controlled conditions, a series of train tests was carried out between II/5/I3 and II/7//3 in the track section between West Falls Church substation and Vienna Station. These included two tests that used the BPS as the sole source of power for train movements. These two tests and the results are summarized Table 3-3.

\begin{tabular}{|c|l|c|}
\hline Test \# & \multicolumn{1}{|c|}{ Test Description } & Consumed BPS SOC (\%) \\
\hline El & $\begin{array}{l}\text { Train I accelerating to } 10 \mathrm{mph} \text { and maintaining this } \\
\text { speed; traveling a distance of 2,800'; Train 2 outside } \\
\text { of feeding section }\end{array}$ & $4.0 \%$ \\
\hline E2 & $\begin{array}{l}\text { Train 2 accelerating to } 10 \mathrm{mph} \text { and maintaining this } \\
\text { speed; traveling a distance of 2,800'; Train I remaining } \\
\text { stationary and drawing auxiliary power only }\end{array}$ & $6.4 \%$ \\
\hline
\end{tabular}

All trains are of 6-car trains at AWO load, with mixed car types.

As shown in Table 3-3, Test El indicates that to move one 6-car train with empty cars $(82,500 \mathrm{lb}$ per car) from standstill by 2,800 feet at a maximum speed of 10 $\mathrm{mph}, 4 \%$ of the BPS full-charge energy is consumed. If the same train is on crush load (AW2 load with 175 passengers in each car), the energy consumption is as shown in Table 3-4. 


\section{Table 3-4}

Adjustment of Energy Consumption for Train Movements from Empty Train Load (AWO) to Crush Train Load (AW2)

\begin{tabular}{|c|c|c|c|}
\hline Parameters & $\begin{array}{l}\text { AWO Load } \\
\text { (0 passengers) }\end{array}$ & $\begin{array}{c}\text { AW2 Load } \\
\text { (175 passengers } \\
\text { per car) }\end{array}$ & Ratio AW2/AWo \\
\hline AW0 load (lb/car) & 82,500 & 82,500 & \\
\hline Rotational allowance (\% of AW0) & $5 \%$ & $5 \%$ & \\
\hline Rotational weight (lb/car) & 4,125 & 4,125 & \\
\hline Number of passengers per car & 0 & 175 & \\
\hline Passenger weight (lb/person) & 154 & 154 & \\
\hline Total passenger weight (lb/car) & 0 & 26,950 & \\
\hline Effective total weight (lb/car) & 86,625 & 113,575 & $131.1 \%$ \\
\hline $\begin{array}{l}\text { BPS energy consumption ( } \% \text { of SOC) for moving } \\
\text { a } 6 \text {-car train by } 2800^{\prime}\end{array}$ & $4.00 \%$ & $5.24 \%$ & $\begin{array}{l}\text { Scaling based on } \\
\text { effective weight ratio }\end{array}$ \\
\hline $\begin{array}{l}\text { Number of trains that can be moved by } 2800 \text { ' } \\
\text { by using BPS at } 100 \% \text { SOC }\end{array}$ & 25.0 & 19.1 & \\
\hline $\begin{array}{l}\text { Number of trains that can be moved by } 4000 \text { ' } \\
\text { by using BPS at } 100 \% \text { SOC }\end{array}$ & 17.5 & 13.3 & \\
\hline
\end{tabular}

From this test and the calculations above, it can be seen that a fully-charged BPS can move 19 crush-loaded (AW2) 6-car trains by 2,800 feet in succession until the BPS energy is depleted, assuming that no other train draws power from the BPS at the same time.

If the required distance to move the train is different from 2,800 feet, the number of trains that can be moved can be calculated according to the proportion of 2,800 feet over the required distance. For example, to move the trains by 4,000 feet under the same condition, the number of AW2 loaded 6-car trains that can be moved by 4,000 feet is 13 .

As illustrated in Test E2 results, stationary trains that draw auxiliary load from the BPS will impact the state of charge (SOC) of the BPS. The impact on the SOC of the BPS depends on how much power is being drawn and for how long. Consequently, the number of trains that can be moved by the BPS power will vary.

\section{Summary of Train Test Results}

In addition to the emergency power test described above, other tests were performed to prove the BPS effects on voltage stabilization BPS reception of regenerative power or current. Table 35 presents a summary of the voltage stabilization effects of the BPS. 


\section{Table 3-5}

Summary of Train Test Results - Voltage Stabilization by BPS

\begin{tabular}{|c|c|c|c|c|c|c|}
\hline Test \# & Test Details & $\begin{array}{c}\text { Test Descrip- } \\
\text { tions }\end{array}$ & $\begin{array}{l}\text { Observed } \\
\text { Parameters }\end{array}$ & $\begin{array}{l}\text { Without } \\
\text { BPS }\end{array}$ & With BPS & $\begin{array}{c}\text { BPS Voltage } \\
\text { Stabilization (V) }\end{array}$ \\
\hline VI & $\begin{array}{l}\text { Day I Test I-I; } \\
\text { Day } 2 \text { Test I-2 }\end{array}$ & $\begin{array}{l}\text { I train } \\
\text { accelerating at } \\
\text { full power }\end{array}$ & Voltage drop (V) & 60 & 56 & 4 \\
\hline V2 & $\begin{array}{l}\text { Day I Test 2-I; } \\
\text { Day } 2 \text { Test 2-2 }\end{array}$ & $\begin{array}{l}\text { I train braking } \\
\text { at full-service } \\
\text { braking }\end{array}$ & Voltage rise $(\mathrm{V})$ & 65 & 37 & 28 \\
\hline V3 & $\begin{array}{l}\text { Day I Test 3-2; } \\
\text { Day } 2 \text { Test 3-I }\end{array}$ & $\begin{array}{c}\text { I train } \\
\text { accelerating and } \\
\text { I train braking }\end{array}$ & $\begin{array}{l}\text { Voltage variation } \\
\text { (minimum to } \\
\text { maximum) }\end{array}$ & 120 & 82 & 38 \\
\hline V4 & $\begin{array}{l}\text { Day } 3 \text { Test I-2; } \\
\text { Day } 3 \text { Test 2-I }\end{array}$ & $\begin{array}{l}2 \text { trains } \\
\text { accelerating at } \\
\text { full power }\end{array}$ & $\begin{array}{l}\text { Voltage variation } \\
\text { (minimum to } \\
\text { maximum) }\end{array}$ & 218 & 143 & 75 \\
\hline V5 & $\begin{array}{l}\text { Day } 3 \text { Test } \\
\text { IA-I; Day } 3 \\
\text { Test } \\
2 A-2\end{array}$ & $\begin{array}{l}2 \text { trains braking } \\
\text { at full-service } \\
\text { braking; WFC } \\
\text { rectifiers offline }\end{array}$ & Voltage rise $(\mathrm{V})$ & 59 & 28 & 31 \\
\hline
\end{tabular}

Note: Track section between Barbour Rd substation and Fisher St substation was fed by West Falls Church substation only. Voltages were recorded in West Falls Church substation.

Table 3-6 presents a summary of the captured energy by the BPS from the regenerative train and the maximum charging currents.

\section{Table 3-6}

Summary of Train Test Results - Reception of Regenerated Energy and Maximum Charging Current

\begin{tabular}{|c|c|c|c|c|}
\hline Test \# & Test Details & Test Descriptions & Observed Parameters & $\begin{array}{c}\text { BPS } \\
\text { Reception }\end{array}$ \\
\hline RI & $\begin{array}{l}\text { Day I Test } 2-1 \text {; } \\
\text { Day } 2 \text { Test } 2-2\end{array}$ & I train braking at full service braking & captured energy ( $\mathrm{kWh}$ ) & 3.94 \\
\hline $\mathrm{R} 2$ & $\begin{array}{l}\text { Day I Test 3-2; } \\
\text { Day } 2 \text { Test 3-I }\end{array}$ & I train accelerating and I train braking & captured energy (kWh) & 1.40 \\
\hline R3 & Day 3 Test $2 A-2$ & 2 trains braking at B5 mode & captured energy (kWh) & 7.74 \\
\hline R4 & Day 3 Test 2B & 2 trains braking at $\mathrm{B} 3$ mode & captured energy (kWh) & 8.91 \\
\hline R5 & Day 2 Test 4 & $\begin{array}{l}\text { I train braking at full-service braking in } \\
\text { Dunn Loring Station (II,618' from WFC) }\end{array}$ & $\begin{array}{l}\text { maximum charging } \\
\text { current }(A)\end{array}$ & 820 \\
\hline R6 & Day 2 Test 4 & $\begin{array}{l}\text { I train braking at full service braking in } \\
\text { Vienna Station }(24,187 \text { ' from WFC) }\end{array}$ & $\begin{array}{l}\text { maximum charging } \\
\text { current }(A)\end{array}$ & 304 \\
\hline
\end{tabular}

Note: Track section between Barbour Rd substation and Fisher St substation was fed by West Falls Church substation only for tests RI to R4. For tests R5 and R6, normal feeding arrangement was used. 
Tests R5 and R6 demonstrate how far the BPS can reach to capture regenerative power in the traction power system. When the braking train was II,618 feet (2.2 miles) away from the BPS, the BPS absorbed 820 Amps from the train (or $574 \mathrm{~kW}$ at 700V). When the braking train was 24,187 feet (4.6 miles) away from the BPS, the BPS absorbed 304 Amps from the train (or $213 \mathrm{~kW}$ at $700 \mathrm{~V}$ ). 


\section{SECTION 4 \\ Return-on-Investment (ROI) Calculations \\ Potential Energy Cost Savings \\ Based on the annual energy savings listed in Table 32 , the potential cost savings due to reduced energy consumption and reduced peak power demand were calculated for scenarios $\mathrm{A}$ and $\mathrm{C}$. \\ Scenario A \\ For Scenario A, the potential cost savings due to reduced energy consumption under a range of electricity prices are listed in Table 4-I.}

Table 4-1

Potential Energy Cost Savings Scenario A

\begin{tabular}{|c|c|c|c|c|c|}
\hline $\begin{array}{c}\text { Cost } \\
(\$ / k W h)\end{array}$ & Year I & Year 5 & Year 10 & Year 15 & Year 20 \\
\hline$\$ 0.070$ & $\$ 44,965$ & $\$ 235,878$ & $\$ 501,454$ & $\$ 800,465$ & $\$ 1,137,122$ \\
\hline$\$ 0.080$ & $\$ 51,388$ & $\$ 269,575$ & $\$ 573,090$ & $\$ 914,817$ & $\$ 1,299,568$ \\
\hline$\$ 0.090$ & $\$ 57,812$ & $\$ 303,272$ & $\$ 644,726$ & $\$ 1,029,169$ & $\$ 1,462,014$ \\
\hline$\$ 0.100$ & $\$ 64,236$ & $\$ 336,969$ & $\$ 716,362$ & $\$ 1,|43,52|$ & $\$ 1,624,460$ \\
\hline$\$ 0.110$ & $\$ 70,659$ & $\$ 370,666$ & $\$ 787,999$ & $\$ 1,257,873$ & $\$ 1,786,906$ \\
\hline$\$ 0.120$ & $\$ 77,083$ & $\$ 404,363$ & $\$ 859,635$ & $\$ 1,372,226$ & $\$ 1,949,351$ \\
\hline$\$ 0.124$ & $\$ 79,652$ & $\$ 417,842$ & $\$ 888,289$ & $\$ 1,417,966$ & $\$ 2,014,330$ \\
\hline$\$ 0.130$ & $\$ 83,506$ & $\$ 438,060$ & $\$ 931,27 \mid$ & $\$ 1,486,578$ & $\$ 2,111,797$ \\
\hline$\$ 0.140$ & $\$ 89,930$ & $\$ 47 \mid, 757$ & $\$ 1,002,907$ & $\$ 1,600,930$ & $\$ 2,274,243$ \\
\hline$\$ 0.150$ & $\$ 96,353$ & $\$ 505,454$ & $\$ 1,074,544$ & $\$ 1,715,282$ & $\$ 2,436,689$ \\
\hline$\$ 0.160$ & $\$ 102,777$ & $\$ 539,150$ & $\$ 1,146,180$ & $\$ 1,829,634$ & $\$ 2,599,135$ \\
\hline
\end{tabular}

Note: Electricity cost escalated 2.4\% per year; $\mathrm{kWh}$ savings per week $=12,353$

Electricity cost varies widely according to geographical area. As of May 2015, the average electricity cost in the Washington, DC area was $\$ 0.124 / \mathrm{kWh}$, according to a publication of U.S. Bureau of Labor Statistics [4]. This is shown in Figure 4-I0. 


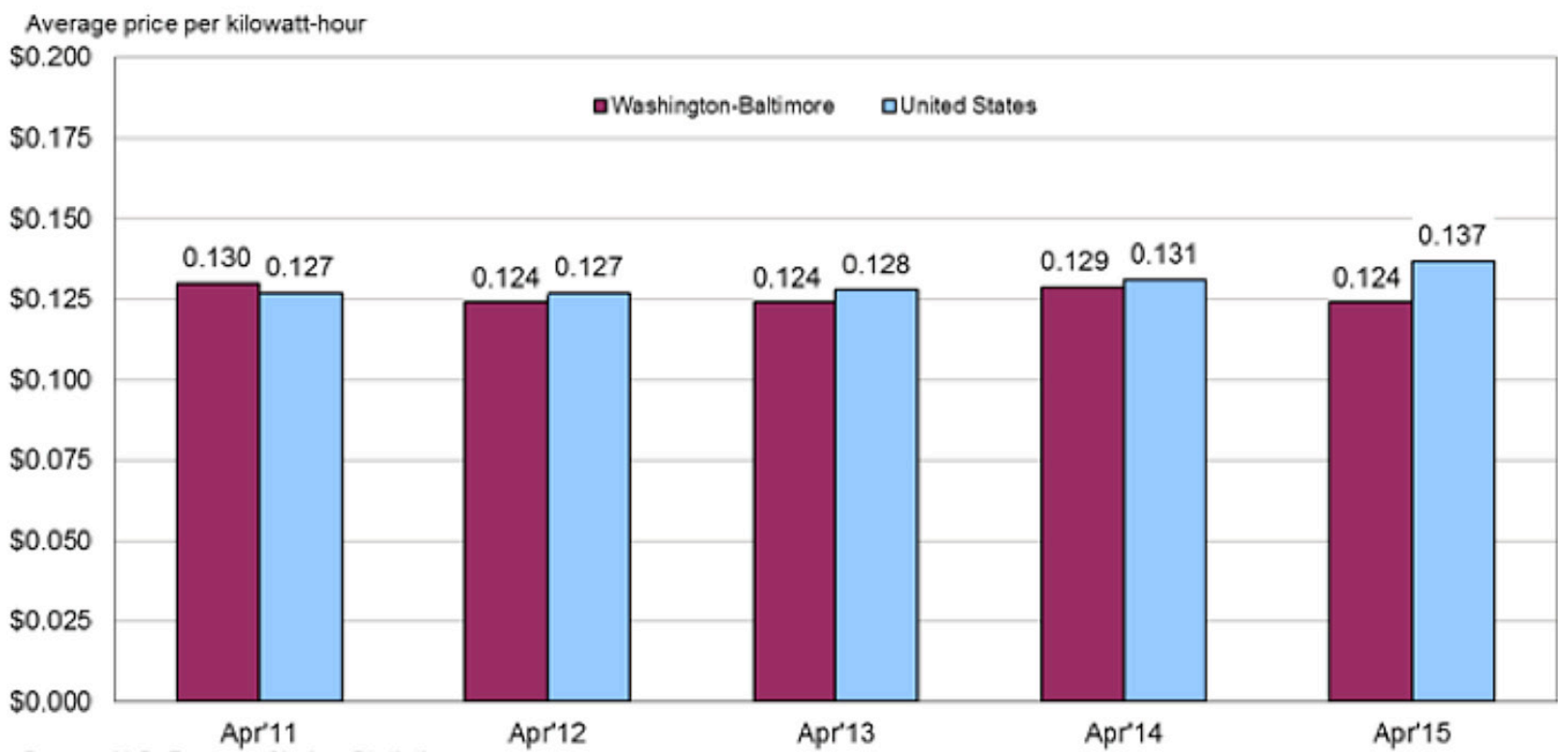

Figure 4-1

Average Prices for Electricity for Washington-Baltimore Area

Potential cost savings under the price of $\$ 0.124 / \mathrm{kWh}$ for the Washington/ Baltimore are highlighted in bold in Table 4 -I.

The electricity cost increase of $2.4 \%$ per yer is the national average that is projected in a publication by the U.S. Energy Information Administration [3]. No projected data were found for regional cost increases.

The potential cost savings due to reduced peak power demand under different demand charges are illustrated in Table 4-2.

Table 4-2

Potential Peak Power

Cost Savings -

Scenario A

\begin{tabular}{|c|c|c|c|c|c|}
\hline $\begin{array}{c}\text { Cost } \\
(\$ / k W)\end{array}$ & Year I & Year 5 & Year I0 & Year I5 & Year 20 \\
\hline$\$ 5.00$ & $\$ 16,620$ & $\$ 87,186$ & $\$ 185,348$ & $\$ 295,869$ & $\$ 420,305$ \\
\hline$\$ 10.00$ & $\$ 33,240$ & $\$ 174,371$ & $\$ 370,696$ & $\$ 591,738$ & $\$ 840,609$ \\
\hline$\$ 15.00$ & $\$ 49,860$ & $\$ 261,557$ & $\$ 556,044$ & $\$ 887,607$ & $\$ 1,260,914$ \\
\hline$\$ 20.00$ & $\$ 66,480$ & $\$ 348,743$ & $\$ 741,392$ & $\$ 1,183,476$ & $\$ 1,681,218$ \\
\hline$\$ 25.00$ & $\$ 83,100$ & $\$ 435,928$ & $\$ 926,740$ & $\$ 1,479,345$ & $\$ 2,101,523$ \\
\hline
\end{tabular}

Note: Electricity cost escalated $2.4 \%$ per year; peak power $\mathrm{kW}$ reduction $=277$.

Peak power demand charges vary widely according to geographical area. As there are no peak power charges in the Washington, DC / Baltimore area, no cost savings from peak power reduction were counted in the ROI calculations in this report. 


\section{Scenario C}

For Scenario $C$, the cost savings due to reduced energy consumption are listed in Table 4-3.

\section{Table 4-3 \\ Potential Energy \\ Cost Savings - \\ Scenario C}

\section{Table 4-4 \\ Potential Peak Power \\ Cost Savings - \\ Scenario $C$}

\begin{tabular}{|c|c|c|c|c|c|}
\hline $\begin{array}{c}\text { Cost } \\
(\$ / k W)\end{array}$ & Year I & Year 5 & Year I0 & Year I5 & Year 20 \\
\hline$\$ 0.070$ & $\$ 94,316$ & $\$ 494,766$ & $\$ 1,051,823$ & $\$ 1,679,013$ & $\$ 2,385,166$ \\
\hline$\$ 0.080$ & $\$ 107,790$ & $\$ 565,447$ & $\$ 1,202,083$ & $\$ 1,918,872$ & $\$ 2,725,904$ \\
\hline$\$ 0.090$ & $\$ 121,263$ & $\$ 636,128$ & $\$ 1,352,343$ & $\$ 2,158,731$ & $\$ 3,066,642$ \\
\hline$\$ 0.100$ & $\$ 134,737$ & $\$ 706,808$ & $\$ 1,502,604$ & $\$ 2,398,590$ & $\$ 3,407,381$ \\
\hline$\$ 0.110$ & $\$ 148,211$ & $\$ 777,489$ & $\$ 1,652,864$ & $\$ 2,638,449$ & $\$ 3,748,119$ \\
\hline$\$ 0.120$ & $\$ 161,685$ & $\$ 848,170$ & $\$ 1,803,125$ & $\$ 2,878,308$ & $\$ 4,088,857$ \\
\hline$\$ 0.124$ & $\$ 167,074$ & $\$ 876,442$ & $\$ 1,863,229$ & $\$ 2,974,25 I$ & $\$ 4,225,152$ \\
\hline$\$ 0.130$ & $\$ 175,158$ & $\$ 918,851$ & $\$ 1,953,385$ & $\$ 3,118,167$ & $\$ 4,429,595$ \\
\hline$\$ 0.140$ & $\$ 188,632$ & $\$ 989,532$ & $\$ 2,103,645$ & $\$ 3,358,026$ & $\$ 4,770,333$ \\
\hline$\$ 0.150$ & $\$ 202,106$ & $\$ 1,060,213$ & $\$ 2,253,906$ & $\$ 3,597,885$ & $\$ 5, I I 1,07 I$ \\
\hline$\$ 0.160$ & $\$ 215,580$ & $\$ 1,130,893$ & $\$ 2,404,166$ & $\$ 3,837,744$ & $\$ 5,451,809$ \\
\hline
\end{tabular}

Notes: Electricity cost escalated $2.4 \%$ per year; $\mathrm{kWh}$ savings per week $=25,91 \mathrm{I}$

Potential cost savings for Scenario $C$ at $\$ 0.124 / \mathrm{kWh}$ are highlighted in bold in the above table.

The potential cost savings due to reduced peak power demand under different demand charges are illustrated in Table 4-4.

\begin{tabular}{|c|c|c|c|c|c|}
\hline $\begin{array}{c}\text { Cost } \\
(\$ / k W)\end{array}$ & Year I & Year 5 & Year I0 & Year I5 & Year 20 \\
\hline$\$ 5.00$ & $\$ 26,160$ & $\$ 137,231$ & $\$ 291,739$ & $\$ 465,700$ & $\$ 661,562$ \\
\hline$\$ 10.00$ & $\$ 52,320$ & $\$ 274,462$ & $\$ 583,478$ & $\$ 931,400$ & $\$ 1,323,125$ \\
\hline$\$ 15.00$ & $\$ 78,480$ & $\$ 411,693$ & $\$ 875,217$ & $\$ 1,397,100$ & $\$ 1,984,687$ \\
\hline$\$ 20.00$ & $\$ 104,640$ & $\$ 548,924$ & $\$ 1,166,957$ & $\$ 1,862,800$ & $\$ 2,646,250$ \\
\hline$\$ 25.00$ & $\$ 130,800$ & $\$ 686,154$ & $\$ 1,458,696$ & $\$ 2,328,500$ & $\$ 3,307,812$ \\
\hline
\end{tabular}

Similar to Scenario A, no cost savings from peak power reduction were counted in the ROI calculations for Scenario $C$ in this report.

\section{Return-on-Investment}

Calculations for ROI were conducted according to the following equations.

On the cost side, the components are:

\section{Total Cost $=($ Equipment Cost + Maintenance Cost $)-$ (Cost for Displaced Investment)}


Where the "Cost for Displaced Investment" represents the cost that may be needed for an alternative installation (such as a traditional rectifier) to achieve the same effects as the BPS installation. This cost is used as an offset item for the total cost that is needed for a BPS installation.

On the saving side, the components are:

\section{Total Saving $=($ Energy Cost Saving $)$ + (Peak Demand Power Cost Saving)}

The ROI is obtained as:

$$
\text { ROI }=(\text { Total Saving }- \text { Total Cost }) /(\text { Total Cost }) \times 100 \%
$$

The equipment cost includes cost of installation. The cost for displaced investment includes equipment cost (including cost of installation) and maintenance cost.

\section{ROI at 10 Years}

The calculations for ROI at 10 years for Scenario A are listed in Table 4-5.

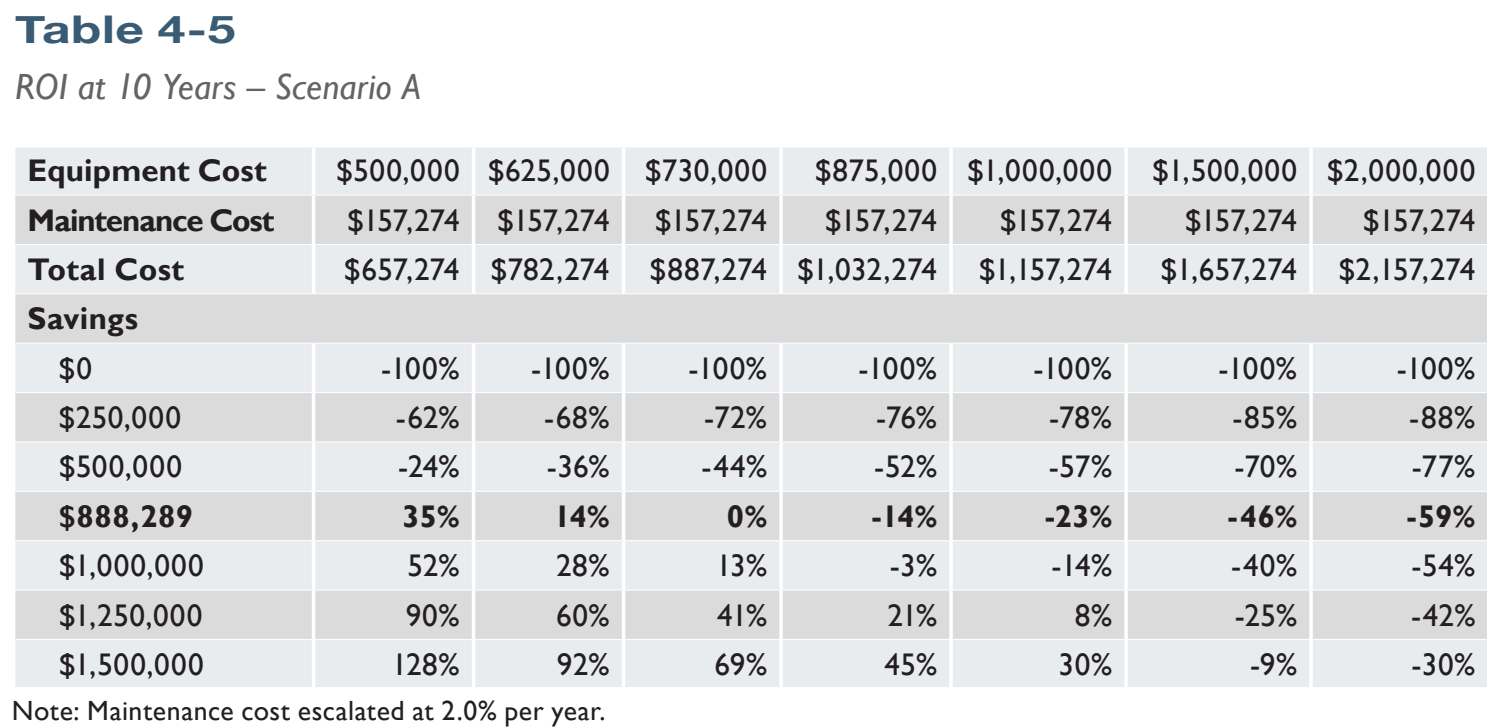

The $2 \%$ cost escalation per year for maintenance is based on the best estimation for the general trend of labor cost inflation. This is because no official project data were available.

This table indicates that for Scenario $A$ to be financially viable at 10 years (the break-event point), the equipment cost (offset by additional benefits and cost for displaced investment that are not yet quantified) needs be at or less than $\$ 730,000$. 
The calculations for ROI at 10 years for Scenario $C$ are listed in Table 4-6.

Table 4-6

Return on Investment at 10 Years - Scenario C

\begin{tabular}{|l|r|r|r|r|r|r|r|}
\hline $\begin{array}{l}\text { Equipment Cost } \\
\text { Maintenance Cost }\end{array}$ & $\$ 1,000,000$ & $\$ 1,500,000$ & $\$ 1,750,000$ & $\$ 1,870,000$ & $\$ 2,000,000$ & $\$ 2,250,000$ & $\$ 2,750,000$ \\
\hline Total Cost & $\$ 1,157,274$ & $\$ 1,657,274$ & $\$ 1,907,274$ & $\$ 2,157,274$ & $\$ 2,157,274$ & $\$ 2,407,274$ & $\$ 2,907,274$ \\
\hline Savings & $-100 \%$ & $-100 \%$ & $-100 \%$ & $-100 \%$ & $-100 \%$ & $-100 \%$ & $-100 \%$ \\
\hline$\$ 0$ & $0 \%$ & $-33 \%$ & $-43 \%$ & $-47 \%$ & $-50 \%$ & $-56 \%$ & $-64 \%$ \\
\hline$\$ 1,000,000$ & $50 \%$ & 0 & $-14 \%$ & $-20 \%$ & $-25 \%$ & $-33 \%$ & $-45 \%$ \\
\hline$\$ 1,500,000$ & $75 \%$ & $17 \%$ & $0 \%$ & $-6 \%$ & $-13 \%$ & $-22 \%$ & $-36 \%$ \\
\hline$\$ 1,750,000$ & $\mathbf{8 6} \%$ & $24 \%$ & $6 \%$ & $0 \%$ & $-7 \%$ & $-17 \%$ & $-32 \%$ \\
\hline$\$ 1,863,229$ & $100 \%$ & $33 \%$ & $14 \%$ & $7 \%$ & $0 \%$ & $-11 \%$ & $-27 \%$ \\
\hline$\$ 2,000,000$ & $150 \%$ & $67 \%$ & $43 \%$ & $34 \%$ & $25 \%$ & $11 \%$ & $-9 \%$ \\
\hline$\$ 2,500,000$ & & & & & & & \\
\hline
\end{tabular}

This table indicates that, for Scenario $C$ to be financially viable at 10 years (i.e., the break-even point), the equipment cost (offset by additional benefits and cost for displaced investment that are not yet quantified) needs to at or less than $\$ 1,870,000$.

ROI at 20 Years

The calculations for ROI at 20 years for Scenario A are listed in Table 4-7.

\section{Table 4-7}

Return on Investment at 20 Years - Scenario A

\begin{tabular}{|c|c|c|c|c|c|c|c|}
\hline Equipment Cost & $\$ 250,000$ & $\$ 410,000$ & $\$ 500,000$ & $\$ 750,000$ & $\$ 1,000,000$ & $\$ 1,500,000$ & $\$ 2,000,000$ \\
\hline Maintenance Cost & $\$ 1,594,403$ & $\$ 1,594,403$ & $\$ 1,594,403$ & $\$ 1,594,403$ & $\$ 1,594,403$ & $\$ 1,594,403$ & $\$ 1,594,403$ \\
\hline Total Cost & $\$ 1,844,403$ & $\$ 2,004,403$ & $\$ 2,094,403$ & $\$ 2,344,403$ & $\$ 2,594,403$ & $\$ 3,094,403$ & $\$ 3,594,403$ \\
\hline \multicolumn{8}{|l|}{ Savings } \\
\hline$\$ 0$ & $-100 \%$ & $-100 \%$ & $-100 \%$ & $-100 \%$ & $-100 \%$ & $-100 \%$ & $-100 \%$ \\
\hline$\$ 1,000,000$ & $-46 \%$ & $-50 \%$ & $-52 \%$ & $-57 \%$ & $-61 \%$ & $-68 \%$ & $-72 \%$ \\
\hline$\$ 1,500,000$ & $-19 \%$ & $-25 \%$ & $-28 \%$ & $-36 \%$ & $-42 \%$ & $-52 \%$ & $-58 \%$ \\
\hline$\$ 2,014,330$ & $9 \%$ & $0 \%$ & $-4 \%$ & $-14 \%$ & $-22 \%$ & $-35 \%$ & $-44 \%$ \\
\hline$\$ 2,250,000$ & $22 \%$ & $12 \%$ & $7 \%$ & $-4 \%$ & $-13 \%$ & $-27 \%$ & $-37 \%$ \\
\hline$\$ 2,500,000$ & $36 \%$ & $25 \%$ & $19 \%$ & $7 \%$ & $-4 \%$ & $-19 \%$ & $-30 \%$ \\
\hline$\$ 2,750,000$ & $49 \%$ & $37 \%$ & $31 \%$ & $17 \%$ & $6 \%$ & $-11 \%$ & $-23 \%$ \\
\hline
\end{tabular}

Note: Maintenance cost escalated at $2.0 \%$ per year; maintenance cost includes battery change at year 10

This table indicates that for Scenario $A$ to be financially viable at 20 years (the break-event point), the equipment cost (offset by additional benefits and cost for displaced investment that are not yet quantified) needs be at or less than $\$ 410,000$. 
The calculations for $\mathrm{ROI}$ at 20 years for Scenario $\mathrm{C}$ are listed in Table 4-8

Table 4-8

Return on Investment at 20 Years - Scenario C

\begin{tabular}{|c|c|c|c|c|c|c|c|}
\hline Equipment Cost & $\$ 1,000,000$ & $\$ 1,500,000$ & $\$ 2,000,000$ & $\$ 2,500,000$ & $\$ 2,650,000$ & $\$ 2,750,000$ & $\$ 3,000,000$ \\
\hline Maintenance Cost & $\$ 1,594,403$ & $\$ 1,594,403$ & $\$ 1,594,403$ & $\$ 1,594,403$ & $\$ 1,594,403$ & $\$ 1,594,403$ & $\$ 1,594,403$ \\
\hline Total Cost & $\$ 2,594,403$ & $\$ 3,094,403$ & $\$ 3,594,403$ & $\$ 4,094,403$ & $\$ 4,244,403$ & $\$ 4,344,403$ & $\$ 4,594,403$ \\
\hline \multicolumn{8}{|l|}{ Savings } \\
\hline$\$ 0$ & $-100 \%$ & $-100 \%$ & $-100 \%$ & $-100 \%$ & $-100 \%$ & $-100 \%$ & $-100 \%$ \\
\hline$\$ 1,000,000$ & $-61 \%$ & $-68 \%$ & $-72 \%$ & $-76 \%$ & $-76 \%$ & $-77 \%$ & $-78 \%$ \\
\hline$\$ 2,000,000$ & $-23 \%$ & $-35 \%$ & $-44 \%$ & $-51 \%$ & $-53 \%$ & $-54 \%$ & $-56 \%$ \\
\hline$\$ 3,000,000$ & $16 \%$ & $-3 \%$ & $-17 \%$ & $-27 \%$ & $-29 \%$ & $-31 \%$ & $-35 \%$ \\
\hline$\$ 4,000,000$ & $54 \%$ & $29 \%$ & $11 \%$ & $-2 \%$ & $-6 \%$ & $-8 \%$ & $-13 \%$ \\
\hline$\$ 4,225,152$ & $63 \%$ & $37 \%$ & $18 \%$ & $3 \%$ & $0 \%$ & $-3 \%$ & $-8 \%$ \\
\hline$\$ 5,000,000$ & $93 \%$ & $62 \%$ & $39 \%$ & $22 \%$ & $18 \%$ & $15 \%$ & $9 \%$ \\
\hline$\$ 6,000,000$ & $131 \%$ & $94 \%$ & $67 \%$ & $47 \%$ & $41 \%$ & $38 \%$ & $31 \%$ \\
\hline$\$ 7,000,000$ & $170 \%$ & $126 \%$ & $95 \%$ & $71 \%$ & $65 \%$ & $61 \%$ & $52 \%$ \\
\hline
\end{tabular}

Note: Maintenance cost escalated at $2.0 \%$ per year; Maintenance cost includes battery change at year 10.

This table indicates that for Scenario $C$ to be financially viable at 20 years (the break-event point), the equipment cost (offset by additional benefits and cost for displaced investment that are not yet quantified) needs be at or less than $\$ 2,650,000$.

\section{Other Benefits}

In addition to energy cost savings, the BPS also will bring other benefits to the system owner, as follows:

- Voltage support for trains so that the traction power system can effectively support the desired train service levels.

- Emergency power to trains in traction power blackout situations-this is particularly valuable in tunnel environments where the requirements for safety evacuation of passengers are more demanding than open track environment.

- Significant capital cost savings if a BPS can be installed in place of one or more traditional rectifier units.

- Where the site conditions do not permit installations of traditional rectifier units.

Quantification of these additional benefits is dependent on the actual situation. The realization of these benefits may significantly improve the ROI calculation results. This is consistent with the findings from a previously-published study by 
the Transit Cooperative Research Program [5]: an energy storage installation in a rail transit environment is most practical when it realizes more than one benefit simultaneously rather than focusing the application primarily on solving any one problem alone. 


\section{APPENDIX Summary of A Recorded Data}

\section{Table A-1}

Summary of Recorded Data

\begin{tabular}{|c|c|c|c|c|c|c|c|c|c|c|}
\hline \multicolumn{3}{|c|}{ Scenarios } & \multirow[b]{2}{*}{ Date } & \multicolumn{3}{|c|}{ Substation Energy (kWh) } & \multirow{2}{*}{$\begin{array}{c}\text { BPS } \\
\text { Discharge } \\
\text { Energy } \\
\text { (kWh) }\end{array}$} & \multirow{2}{*}{$\begin{array}{c}\text { BPS } \\
\text { Charge } \\
\text { Energy } \\
\text { (kWh) }\end{array}$} & \multirow[b]{2}{*}{$\begin{array}{l}\text { Number } \\
\text { of Cars } \\
\text { per Day }\end{array}$} & \multirow[b]{2}{*}{$\begin{array}{c}\text { Avg } \\
\text { Temperature } \\
\text { (Deg. F) }\end{array}$} \\
\hline Test \# & $\begin{array}{c}\text { WFC } \\
\text { TPS } \\
\text { Status }\end{array}$ & $\begin{array}{l}\text { BPS } \\
\text { Status }\end{array}$ & & $\begin{array}{l}\text { Barbour } \\
\text { Rd TPS }\end{array}$ & $\begin{array}{l}\text { WFC } \\
\text { TPS }\end{array}$ & $\begin{array}{l}\text { Fisher } \\
\text { St TPS }\end{array}$ & & & & \\
\hline \multirow{7}{*}{$\mathrm{BI}$} & \multirow{7}{*}{$3 M W$} & \multirow{7}{*}{ OFF } & $8 / 19 / 2013$ & 8,589 & 9,726 & 10,106 & \multirow{7}{*}{\multicolumn{2}{|c|}{$\mathrm{n} / \mathrm{a}$}} & 1,962 & 70 \\
\hline & & & $8 / 20 / 2013$ & 9,187 & 9,693 & 10,504 & & & 1,990 & 79 \\
\hline & & & $8 / 21 / 2013$ & 8,975 & 10,279 & 10,983 & & & 1,916 & 81 \\
\hline & & & $8 / 22 / 2013$ & 9,368 & 10,453 & 11,658 & & & 1,976 & 83 \\
\hline & & & $8 / 23 / 2013$ & 9,755 & 10,135 & 10,809 & & & 1,996 & 73 \\
\hline & & & $8 / 24 / 2013$ & 6,891 & 6,834 & 7,860 & & & 1,380 & 75 \\
\hline & & & $8 / 25 / 2013$ & 6,242 & 6,517 & 7,349 & & & 1,230 & 74 \\
\hline \multirow{7}{*}{ B2 } & \multirow{7}{*}{$3 M W$} & \multirow{7}{*}{ ON } & $8 / 26 / 2013$ & 8,564 & 9,505 & 11,153 & 2,642 & 2,851 & 1,958 & 77 \\
\hline & & & $8 / 27 / 2013$ & \multicolumn{3}{|c|}{$\begin{array}{l}\text { Unscheduled Outage - East } \\
\text { Falls Church Substation Offline }\end{array}$} & 2,699 & 2,881 & 1,944 & 84 \\
\hline & & & $8 / 28 / 2013$ & 9,102 & 9,822 & $|I, 20|$ & 2,925 & 3,083 & 2,066 & 79 \\
\hline & & & $8 / 29 / 2013$ & 8,855 & 8,933 & 11,826 & 2,792 & 3,013 & 1,970 & 81 \\
\hline & & & $8 / 30 / 2013$ & 8,705 & 9,115 & 11,120 & 2,820 & 3,005 & 1,978 & 80 \\
\hline & & & $8 / 31 / 2013$ & \multicolumn{3}{|c|}{$\begin{array}{l}\text { Unscheduled Work - Single } \\
\text { Tracking }\end{array}$} & 2,098 & 2,235 & 454 & 83 \\
\hline & & & $9 / 1 / 2013$ & \multicolumn{3}{|c|}{$\begin{array}{l}\text { Unscheduled Work - Single } \\
\text { Tracking }\end{array}$} & 2,135 & 2,187 & 458 & 83 \\
\hline \multirow{7}{*}{$\mathrm{Cl}$} & \multirow{7}{*}{0} & \multirow{7}{*}{ OFF } & $9 / 9 / 2013$ & 12,850 & 0 & 14,269 & \multirow{7}{*}{\multicolumn{2}{|c|}{$\mathrm{n} / \mathrm{a}$}} & I,982 & 73 \\
\hline & & & $9 / 10 / 2013$ & $|3,7| \mid$ & 0 & 14,410 & & & 2,010 & 83 \\
\hline & & & $9 / 11 / 2013$ & 12,695 & 0 & 15,139 & & & 1,990 & 85 \\
\hline & & & $9 / 12 / 2013$ & 12,913 & 0 & 14,175 & & & 1,956 & 83 \\
\hline & & & $9 / 13 / 2013$ & 12,955 & 0 & 14,323 & & & 2,002 & 72 \\
\hline & & & $9 / 14 / 2013$ & 7,811 & 0 & 8,064 & & & $\mathrm{I}, 074$ & 65 \\
\hline & & & $9 / 15 / 2013$ & 7,397 & 0 & 7,188 & & & 956 & 66 \\
\hline \multirow{7}{*}{$C 2$} & & & $9 / 16 / 2013$ & 11,867 & 0 & 11,517 & 4,112 & 4,337 & 2,010 & 70 \\
\hline & & & $9 / 17 / 2013$ & 11,710 & 0 & 11,830 & 4,227 & 4,506 & 2,024 & 63 \\
\hline & & & $9 / 18 / 2013$ & 11,933 & 0 & 11,066 & 4,192 & 4,582 & 1,994 & 63 \\
\hline & 0 & ON & $9 / 19 / 2013$ & $|2,07|$ & 0 & 11,360 & 4,210 & 4,580 & 1,944 & 67 \\
\hline & & & $9 / 20 / 2013$ & 11,772 & 0 & II,797 & 4,178 & 4,576 & 2,030 & 72 \\
\hline & & & $9 / 21 / 2013$ & 4,645 & 0 & 5,336 & 2,826 & 3,173 & 750 & 72 \\
\hline & & & $9 / 22 / 2013$ & 5,326 & 0 & 5,706 & 2,971 & 3,191 & 918 & 67 \\
\hline & & & $10 / 21 / 2013$ & 6,738 & 11,526 & 9,010 & & & 1,908 & 57 \\
\hline & & & $10 / 22 / 2013$ & 7,319 & 12,650 & 8,919 & & & 1,974 & 60 \\
\hline & & & $10 / 23 / 2013$ & 7,344 & 11,090 & 9,080 & & & I,982 & 54 \\
\hline $\mathrm{Al}$ & $6 \mathrm{MW}$ & OFF & $10 / 24 / 2013$ & 7,671 & 13,139 & 9,451 & $n / a$ & & 2,048 & 48 \\
\hline & & & $10 / 25 / 2013$ & 7,379 & II,524 & 9,982 & & & 2,028 & 48 \\
\hline & & & $10 / 26 / 2013$ & 3,691 & 5,636 & 5,183 & & & $\mathrm{I}, 042$ & 46 \\
\hline & & & $10 / 27 / 2013$ & 3,339 & 5,565 & 4,860 & & & 966 & 53 \\
\hline & & & $10 / 28 / 2013$ & 6,160 & 10,053 & 8,704 & 2,555 & 2,685 & 1,942 & 55 \\
\hline & & & $10 / 29 / 2013$ & 6,772 & 10,640 & 9,022 & 2,669 & 2,787 & 2,012 & 55 \\
\hline & & & $10 / 30 / 2013$ & 6,763 & 10,720 & 8,899 & 2,791 & 2,925 & 1,980 & 59 \\
\hline A2 & $6 \mathrm{MW}$ & ON & $10 / 31 / 2013$ & 6,898 & 10,812 & 8,737 & 2,835 & 2,965 & 1,966 & 62 \\
\hline & & & $1 \mathrm{I} / 1 / 2013$ & 6,398 & 11,616 & 8,567 & 2,696 & 2,840 & 1,956 & 67 \\
\hline & & & $11 / 2 / 2013$ & 4,011 & 5,983 & 5,307 & 2,615 & 2,730 & 1,146 & 62 \\
\hline & & & $11 / 3 / 2013$ & 4,360 & 6,340 & 5,642 & 2,619 & 2,746 & 1,224 & 52 \\
\hline
\end{tabular}

Note: More data were collected in the summary months of 2014. However, the collected data showed significant inconsistency for the days covered. The inconsistency was caused by train service irregularities due to the introduction of test and service trains that run on the new Silver Line, which pass through the test section. It was, therefore, decided that these data were not usable. 
FTA

Office of Technology, Room E43-440

$1200 \mathrm{New}$ Jersey Ave SE

Washington, DC 20590

Roy Chen, Transportation Engineer

Phone: (202) 366-0462

E-mail: RoyWeiShun.Chen@dot.gov

\section{WMATA}

CENI-Office of Chief Engineer, Infrastructure $4 \mathrm{C}-0 \mathrm{I}$ 600 5th St NW

Washington, DC 2000I

Moustapha Ouattara, Assistant Chief Engineer Phone: (202) 962-1023

E-mail: mouattara@wmata.com

\section{Gannett Fleming Transit \& Rail Systems}

85 Mechanic St, Suite E2-2

Lebanon, NH 03766

J. Gordon Yu, Manager of Traction Power Analysis

Phone: (603) 448-4458

E-mail: JYu@gfnet.com

\section{Kawasaki Rail Car, Inc.}

29 Wells Ave, Building \#4

Yonkers, NY I070I

John Calvello, Marketing Sales Manager

Phone: (9l4) 376-4700 ext. 4743

E-mail: calvello@kawasakirailcar.com 
[I] Information about GIGACELL, available at http://www.khi.co.jp/english/gigacell/intro/index. html.

[2] Energy Information Administration, Information about Average U.S. Home Electricity Consumption, available at http://www.eia.gov/tools/faqs/faq.cfm?id=97\&t=3.

[3] U.S. Energy Information Administration, Annual Energy Outlook 2015, Energy Prices, Electricity section (containing projection for price increases from 2013 to 2040 -reference case), available at http://www.eia.gov/forecasts/aeo/section_prices.cfm\#elec.

[4] U.S. Bureau of Labor Statistics, Average Energy Cost in Washington/Baltimore Area, available at http://www.bls.gov/regions/mid-atlantic/news-release/averageenergyprices_ washingtondc.htm.

[5] Transit Cooperative Research Program, "Guiding the Selection and Application of Wayside Energy Storage Technologies for Rail Transit and Electric Utilities,"

TCRP Web-only document 5I, November 2010), available at http://onlinepubs.trb.org/ onlinepubs/tcrp/tcrp_webdoc_5I.pdf. 


\section{2 \\ U.S. Department of Transportation Federal Transit Administration}

U.S. Department of Transportation

Federal Transit Administration

East Building

1200 New Jersey Avenue, SE

Washington, DC 20590

http://www.fta.dot.gov/research 